\title{
Social Networking Brand Engagement using Creative Brand Content Experiences
}

\author{
Khaw Ooi San ${ }^{1}$, Abu Bakar Sade ${ }^{2} \&$ Linda Seduram ${ }^{1}$ \\ ${ }^{1}$ Faculty of Business and Information Science, UCSI University, Kuala Lumpur, Malaysia. \\ ${ }^{2}$ Putra Business School, University Putra Malaysia, Selangor, Malaysia. \\ Correspondence: Khaw Ooi San, Faculty of Business and Information Science, UCSI Univerisity, Kuala Lumpur, \\ Malaysia.
}

Received: January 29, 2020

Accepted: March 4, 2020

Online Published: March 20, 2020

doi:10.5539/ibr.v13n4p63

URL: https://doi.org/10.5539/ibr.v13n4p63

\begin{abstract}
In today's environment, societies are free to create and browse online content; marketers therefore to face vexing challenges in drawing expressive social media users to engage with their brands. This current group of users display postmodernism characteristics; i.e. need more for subjective experiences to achieve self-realization. Hence, the creation of consumer brand engagement among expressive social media societies is through content that should be able to provide these experiences. However, there is lack research study on this trend. The objective of this study was to evaluate passive experiential content that users perceived as novelty emotions (i.e. perceived creativity) that leads to intrinsic state of engagements (i.e. cognitive engagement and affective engagement) and to intentional engagement (the activation of willingness of brand clicking activities in social media). This, in turn, creates an advantage for the marketers because from this process if users engage the chances of building a long-term consumer brand engagement relationship is higher. This research study was done on 25-34 year-old Malaysian active expressive social media users who utilised expressive social media sites on a daily basis for at least 3 hours as the sample population from whom to collect data and administer a questionnaire survey with a still image as stimulus using social networking messaging platforms. Data analysis was conducted using IBM SPSS and IBM AMOS software and results showed positive significant relationship within all the 7 constructs which were functional appeal, emotional appeal, vividness, perceived creativity, cognitive engagement, affective engagement and intentional engagement.
\end{abstract}

Keywords: experience marketing, consumer brand engagement, creative, content, expressive social media, postmodernism

\section{Introduction}

Advancements in technology \& high-speed internet access has promoted the rise of expressive social media such as Facebook, Twitter, Instagram and etc. (Kotler, Hermawan \& Setiawan, 2010; Gensler, Volckner, Liu-Thompkins \& Wiertz, 2013). Ever since the global emergence of these platforms, there has been a constant increase in the number of users joining these platforms. Currently there are approximately 3.484 billion expressive social media users that translates to a $45 \%$ social media penetration rate in global population of 7.676 billion people (Kemp, 2019a).Expressive social media societies activities in these platforms actively utilize by social media users for personal usage which are to create, share, like, browse content (Gensler et al., 2013; Statista, 2018) and to connect with family and friends (Statista, 2018).

With a constant increase in the proportion of expressive social media societies, marketers believe that there is a need to tap on these platforms. This is with a view to build marketers' competitive advantage in the current market, by having brand content that is able to create consumer brand engagement (Bloomstein, 2012; Marketing Science Institute [MSI], 2014; MSI, 2016; MSI, 2018; Hollebeek \& Macky, 2019) which in turn promotes brand activities' interaction with social media societies (The Star, 2018; Stelzner, 2018).Marketers believe that the foundation block of engagement begins with brand content consumption which involves reading the passive content, curation by clicking social media button and later co-creation in which in turn give rise to followers (Evans \& Mckee, 2010; Syrdal \& Briggs, 2018; Wang, Malthouse, Calder \& Uzunoglu, 2019; Hollebeek \& Macky, 2019) and creates long-term engagement in the form of a relationship that is able to indirectly drive organizational performance. For instance, for Naked Pizza, 60\% sales came from its' 4000 Twitter followers 
(Donna \& Marek, 2010). Followers help with external employer branding (Sivertzen, Nilsen \& Olafsen, 2013) and the company is able to cut down on advertising expenditure (Nichols, 2013). However, $89 \%$ of brand marketers have not yet found the best way to engage with this group of societies (Stelzner, 2018) based on the fact that, these societies do not engage with brand activities posted by these marketers in expressive social media sites (European Society for Opinion and Marketing Research [Esomar], 2016; Rahim, Abidin \& Abidin, 2015).

The expressive social media societies do not usually engage in brand activities because they are able to freely interpret stories, and organize different kinds of knowledge (Wided, 2012) and display personal emotion publicly (Trigg, 2014).This indicates that societies have shifted from being passive and only satisfied with their basic needs to current needs for internal balance in the process of actively searching for the meaning of life to achieve self-realization (Gonzalez-Cutre, Sicilia, Sierra, Ferriz \& Hagger, 2016; Frankl \& Batthyanay, 2010; Kotler et al., 2010). In other words, they behave in a manner not adherent to rational-critical standards but prefer the inclusion of emotional discussions (Kennedy \& Sommerfeldt, 2015). This phenomenon is named the experience-hungry society (Snel, 2011), or postmodern societies (Cova, 1996), or creative societies (Kotler et al., 2010). This is evident in increased engagement of social media users in social media platforms (e.g. Facebook) because this platform can provide them with the much needed aspects of curiosity, positive emotion, visual and think experiences (Smith, 2013) that are considered pleasurable by users (Palazon, Scillia \& Lopez, 2015) and help establish their identity (Riva, Wiederhold \& Pietro, 2016). The success of the brands McDonald or Starbucks are due to their focus on creating distinctive experiences for the consumers (Michelli, 2007; Chang \& Chieng, 2006).

Hence, researchers have been actively conducting research on the suitable properties of brand content by tracking social media engagement metrics as written in section 2.2.1. However, currently available analysis of brand content too ad hoc and inconsistent to offer a systematic framework (Tafesse \& Wein, 2017; Tafesse \& Wein, 2018) and many of these approaches appeared to be either too complex or too simplistic (Hongxia, Sun \& John, 2014; Valentina \& Laurence, 2019). A limited number of articles have explored this using a theoretical foundation e.g. user \& gratification (U\&G) theory to identify a suitable content strategy to use in expressive social media platforms (Jahn \& Kunz, 2012; Cvijkl \& Michahelles, 2013; Hollebeek \& Macky, 2019). According to Tafesse (2016), there is a limitation in using $U \& G$ theory that uses a multitude of motivation and experiential content is a more standardized and easy way to observe response as well as to conceptualize experiential marketing dimensions as the asset of brand Facebook page (Simon, Brexendorf \& Fassnact,2013;Tafesse. 2016). This is because marketers believe that the 'experiences' concept builds engagement (Cova \& Dalli, 2009; Solem, 2015; Calder, Malthouse \& Schaedel, 2009) and thus the 'experiences concept building relationship' marketing strategy (Kumar \& Kaushik, 2018; Chang \& Chieng, 2006;Smilansky,2009; Cova \& Dalli, 2009). Therefore the 'experience' concept is therefore suitable to study when evaluating consumer brand engagement. The consumer brand engagement strategy is known as multidimensional motivational relational construct (Higgins, 2006; Bowden, 2009; Brodie, Hollebeek, Juric \& Ilic, 2011; Brodie, Ilic, Juric \& Hollebeek, 2013; Hollebeek, 2011b; Solem, 2015) and some other fields look at it as an intrinsic motivational construct (Ryan \& Deci, 2000a; Ryan \& Deci, 2000b; Moore \& Diehl, 2019) indicating that it consist of relationship-character and intrinsic motivation character. Hence, the concept of perceived creativity is integrated to the model in the process of consumer brand engagement (Moors, Ellsworth, Scherer \& Frijda, 2013). Lastly, as regards the multidimensional consumer brand engagement, when the construct is recording based on metrics alone, is unable to capture all consumer brand engagement constructs (Reitz, 2012; Oh, Bellur \& Sundar, 2015). All consumer brand engagement construct help to verify the intrinsic characteristic of consumer brand engagement for this intrinsic character is able to stabilize the brand relationship with the consumer and thus helps to increase the frequency of clicking social media buttons (Ranasinghe \& Samarasinghe, 2019).

Hence, the proposed research model was developed from the postmodernism perspective with an aim more focused on the subjective elements of experience marketing with a view to fill the gap in content in the literature. Thus, experiential content that is perceived by the expressive social media societies as creative, generates the process of consumer brand engagement (i.e. cognitive engagement, affective engagement and intentional engagement) an intrinsic relational construct. The research model was tested on the behavior of 25-34 year-old Malaysian active expressive social media societies.

\section{Literature Review}

\subsection{Expressive Social Media \& Postmodernism Marketing}

Expressive social media is a social networking platform (Kotler et al., 2010) from the ideological technological foundation of 2.0 (Kaplan \& Haenlein, 2010). It consists of a collection of registered users' profile (Trusov, 
Bodapati \& Bucklin, 2010) allowing users to create content such as adding pictures, posting and consuming content, liking or sharing contents, or connecting with the online social networking platform community (Kaplan \& Haenlein, 2010). It is named the 'expressive social media' because it allows users to shout-out their thoughts and emotions not only with text but also with emoji (Trigg, 2014). This therefore offers hyper-reality; meaning it enables user to portray to others their self-image in a virtual world (Riva et al., 2016; Hamouda, 2012) and to enjoy the paradox of juxtaposition (i.e. opposite effect of the reality and virtual world) and allows the user to experience the unexpected, imaginative and creative (Firat, Dholakia \& Venkatesh, 1995).These points show that the expressive social media has shifted to a postmodernism trend which provides affective characterization on the platform such as emoji for the users to create their own personal ID on the virtual platform. This affective characterization has led to high engagement rates among many users (Kemp, 2019a). A high engagement rate indicates the platform has kick-started the success in building a relationship with its' users.

The postmodernism marketing phenomenon is a break in thinking away from the modern, functional and rational (Bouagina \& Triki, 2014) to focus more on the subjective (Sweetman, 2005; Shaw \& Jones, 2005).For, societies' behavior no longer focuses on rationality and money only, but is moving towards individuals that are driven by continuously searching for feelings and sensations that captivate and amaze them (Addis \& Podesta, 2005; Forlani, Pencarelli \& Buratti, 2018). Such behavior makes such individuals less predictable societies (Batra \& Kazmi, 2008). Thus, relationship marketers critique the extendibility of the traditional marketers' approach of the simplistic marketing mix (Addis \& Podesta, 2005). This in reality is far more complex (Addis \& Podesta, 2005) if there is subjective behavior in the process (Bray, 2008). This is followed by, experiential marketers who attack the issues of the consumer rationality, weakness of the traditional consumer behavior theory (Addis \& Podesta, 2005) that oversimplifies marketing realities (Duhring, 2017) and encourages understanding the underlying psychological process for the behavior of postmodernism societies (So et al., 2015); the non-cognitive process including affective lenses (Pham, 2013; Jacoby \& Morrin, 2015). Therefore, the attitudinal model that has emerged during the traditional marketing paradigm has limitation in the current landscape (Weilbacher, 2001; Kitchen, Kerr, Schultz, McColl \& Pals, 2014) marketers have suggested experience and motivation as better concept (Pham, 2013; Gial, Zhang, Paul \& Giala, 2018) to stabilize their brand relationship (Ranasinghe \& Samarasinghe, 2019).

In short, the behaviour of societies has moved to a trend of postmodernism in expressive social media. In this study, the postmodernism marketing strategy is focused on humanized marketing and specifically the experiential marketing concept with a need for pragmatic, visual and feeling experiences, and literature inducing creative emotion, imaginative/curiosity (cognitive engagement) and positive affectionate emotion (affective engagement) to create intentional engagement to motivate the users. Therefore, marketers able to stabilize or strengthen relationship marketing with brand that can create long term engagement in future.

\subsection{Development of Brand Content}

Advertising-centric marketing, also known as traditional advertising, displays content about convincing the customer of the specific value benefits of the product and services sold utilizing mass medium like magazines, TV and radio (Terkan, 2014; Wang et al., 2019; Hollebeek \& Macky, 2019).The content is homogeneous with self-oriented wording (Jefferson \& Tanton, 2013), rewards (Yilmaz, 2017; Duhigg, 2012), scientific discussion (Buckley, 1989), testimonial to endorse (Cohen, 2014), hard-selling (Halberstam, 1993), forced-selling or aggressive-selling (McGovern, 2006) and is concerned with a company's own value (Jefferson \& Tanton, 2013).

Integrated marketing communication perspective, display content; with more focus on functional element and gimmicks that complement the brand with a more customer-focused marketing communication strategy to nourish stakeholder relationships (Takalani, 2015; Belch \& Belch, 2003; Smilansky, 2009). The content, named 'creative ideas' focuses on Janusian concept (Goldenberg, Mazursky \& Solomon, 1999), Yin \& Yang concept (Blasko \& Mokwa, 1986), hard \& soft thinking (Blasko \& Mokwa, 1988), informational and transformational strategy (Kim \& Cheong, 2011), informational and emotional contents (Appelbaum \& Haliburton, 1993), utilitarian and emotional elements (Plessis, 2015), was later named 'creative execution strategy' concept. This concept focuses on marketers to enhance creative ideas in the physical form which can be named appeals and presentation (Sabharwal, 2018; Laskey,Day \& Crask, 1989; Belch \& Belch, 2003; Kivinen, 2014; Amira, 2015). And as time went by, due to marketers being too focused on the growing popularity of loyalty marketing, introduced loyalty card schemes with introduction of discount and financial benefits for repeated purchases, thereby moving back to traditional advertising with hard selling approach by making their brand akin to commodities (Harker \& Engan, 2010; Smilansky, 2009).

When marketers noted this trend, their next level of differentiation in the content was through a postmodern 
trend to manage the consumer brand relationship especially using expressive social media platforms. At this stage, content created was characteristic to attract audiences and focused on providing experiences (Content Marketing Institute [CMI], 2016; Smilansky, 2009; Palmer, 2010), that were unique and interesting (Rahim \& Clemens,2012), useful (Bloomstein, 2012) valuable (Vollero \& Palazzo , 2015;Rancati \& Gordini, 2014) thereby generating positive behavior with the aim of developing consumer brand engagement (Rahim \& Clemens, 2012; Vollero \& Palazzo, 2015; Holliman \& Rowley, 2014; Rancati \& Gordini, 2014) and increase the probability of a long term engagement relationship (Hollebeek \& Macky, 2019).

\subsubsection{Experience Marketing}

The term "experience" has been defined in multiple ways. Maslow's psychologist field named it 'epiphanic' or 'peak experience' and defined it as a short duration experience that arises when something new (McDonald, 2007; Walls, Okumus, Wang \& Kwun, 2011) and Gestalt's psychologist field named 'holistic experience' and defined it as the individual totality of mind, body, and emotions when experiencing reality (Hosany \& Witham, 2010). Anthropology defined experience based on an interface between the environment and the individual internal mechanism (Morris, Pryor, Schindehutte \& Kuratko, 2012). Philosophers viewed experiences as subjective happenings through interaction with reality (Brakus, Schmitt \& Zarantonello, 2009; Schmitt, 2011; Schmitt \& Zarantonello, 2013). Economic schools named it 'experience economy paradigm' which focuses on how individuals consume experience activities in each realm, explaining entertainment and aesthetic experience as passive engagement, and learning experience and participation experience as active engagement (Gilmore \& Pine, 1998; Hosany \& Witham, 2010; Mehmetoglu \& Engen, 2011).

In marketing literature, different schools of thought describe experience differently. Hedonic consumption schools view experience as fantasies, feelings and fun generated by individuals (Clarke, 2013) through hedonic activities, e.g. art (Schmit, 2009). Extraordinary experiences school focuses on experience that elicits feelings, absorption, imagination, is intrinsically rewarding, energizes, enthuses, enjoyable happening with high-risk adventure activities, e.g. rafting, camping (Loeffler, 2004; Celsi et al., 1993; Schouten et al., 2007; Arnould \& Price, 1993). Marketing management schools focus on holistic experience (Zatori, 2013) and believe that the human mind works in holistic way (Carbone \& Haeckel, 1994; Schmitt, 1999) and first conceptualized it as customer or consumer experience. Customer experience is how a company employs the experience module to provide consumer experience. Whereas consumer experience is how the individual perceives experience encounter that is delivered by experience providers (Schmitt \& Zarantonello, 2013; Schmitt, 1999). These experiences include sensory, affective, creative, cognitive, physical and social-identity experiences (Schmitt, 1999). Furthermore, other researchers derived dimensions of sensorial, affective, physical, social and cognitive experience (Fornerino, Guizon-Helme \&Gotteland, 2008), sensory, intellectual, cognitive, pragmatic, lifestyle and relational experience (Gentile, Spiller \& Noci, 2007), sense, feel, think, act and relate experience (Chang \& Chieng, 2006), sensory, intellectual/think, feel/emotional, and behavioral experience (Delgado-Ballester \& Sabiote, 2015) and sensory, intellectual, social and pragmatic experience (Cachero-Martinez \& Vaquez-Casielles, 2017). Then, when experience blended into branding literature to manage brand activities, the concept of experiential branding was derived; it consists of three experiential hybrids of sense-brand appeal, feel-brand appeal and think-brand appeal (Schmit, 1997) and later Brakus et al. (2009) from the perspective of consumer experience, derived the concept of 'brand experience' as subjective, internal consumer responses (sensations, feelings and cognitions) as well as a behavioral response evoked by brand-related stimuli. Researchers agreed that the concept of brand experiences was the umbrella term for the marketing management school due to its broad construct (Skard, Nysveen \& Pedersen, 2011; Schmitt \& Zarantonello, 2013).

From then on, with the birth of internet, it was named 'online brand experience' which mostly focused on providing online brand experience on a website focusing on attractiveness of cookies, variety visual displays, value of money, participating in events (Ha \& Perks, 2005) and later used an extension of technology acceptance model to study the antecedent of online brand experience (Morgan-Thomas \& Veloutsou, 2013). However, to date little, is known about the dimensions of online brand experience based on the humanistic frame experience as a subjective and inner phenomenon (Bujisic, Bilgihan \& Smith, 2015). With the rising of expressive social media, Ashley \& Tuten (2015) suggested the need for experiential appeals from her content analysis study and recently Simon et al. (2013) proposed an online brand experience in Facebook with dimensions of sensory, affective, cognitive, relational, usability and engagement and Tafesse(2016) suggested dimensions of sensations, cognitions, behaviours and social dimensions but without an empirical study. However, the study of content in expressive social media platform to date, mostly focuses on suitable type of content based on characteristics such as vividness of image (De Vries, Gensler \& Leeflang, 2012; Sabate, Berbegal-Mirabent,Canabate \& Lebherz, 2014; Luarn, Lin \& Chiu, 2015;Coursaris,Osch \& Balogh, 2016), functional (Coursaris et al., 2016; 
Kim,Kang, Choi \& Sung, 2016), novelty content (Tafesse, 2015; Syrdal \& Briggs, 2018), transformation (Tafesse \& Wein, 2018), emotional (Lee, Hosanagar \& Nair, 2018), image with text( Kwok \& Yu, 2013; Pancer, Chandler, Poole, \& Noseworth, 2018; Lee et al., 2018; Trefzger, Baccarella \& Voigt, 2016), photos (Hirvijarvi, 2017) by tracking on standardized metrics of engagement such as share, like, comment using interviewing techniques (Syrdal \& Briggs, 2018), text mining(Kwok \& Yu, 2013), content analysis (Swani,Milne \& Brownm 2013; Sabate et al., 2014; Luarn et al., 2015;Coursaris et al., 2016; Trefzger et al., 2016 ),voting (Hirvijarvi, 2017), imagination of any brand (Kim et al., 2016), systemic analysis (Tafesse, 2015), coding (Tafesse \& Wein, 2018) and calculation with Turk software (Pancer et al., 2018; Lee et al., 2018) which show that the trend of study is still in the exploratory phase and there is lack of focus on using an experiential content as a theoretical foundation. With that background, the study aimed to use an experiential content to create the process of consumer brand engagement.

\subsubsection{Experiential Content}

To fill in the gap of yet of empirical study of experiential content with engagement mentioned in section 2.2.1, in this section this study creates components of experiential content. According to Schmitt (1999) experience can only be communicated through experience provider. The experience provider used was the creative execution strategy concept which forms the foundation for this model because this strategy is the basic principles that underpin content in advertising and enhance creative ideas (Tafesse \& Wein, 2017; Sabharwal, 2018).The concepts of creative execution strategy are 'appeals' and 'presentation' as mentioned in section 2.2. For this study, selection of which appeals and presentation to use was done through consideration of concept of experiential branding element and the study of suitable types of content in the expressive social media as mentioned in section 2.2.1. Hence the concept used in this study to research experiential content were functional appeal that provides the individual with pragmatic experience from the content (Cachero -Martinex \& Vazquez-Casielles 2017), emotional appeal that provides the individual with feel experience (Whiting, 2009; Addis \& Holbrook, 2001) and vividness which provides sense or aesthetic experience (Brakus et al., 2009; Schmitt, 1999; Schmitt, 1997; Devitt, 2017) from the content. We still included functional appeal because a brand item still consists of objective characteristics (Addis \& Holbrook, 2001) for its' balance in the experiential content (Simon et al., 2013; Yilmaz, 2017). Think experience and act experience were not applicable to the experiential content because they are active experiences that happen after passive experience (i.e. brand content) (Pine \& Gilmore, 1999). Relational and engagement experience were not included in the experiential content as these experiences are built after passive and active experience (Evans \& Mckee, 2010; Syrdal \& Briggs, 2018; Wang et al., 2019; Hollebeek \& Macky, 2019).

\subsection{Perceived Creativity}

To explain the perceived creativity construct, creativity was explained based on the reaction from evaluation of content creative by users. This is because in the social system of creativity, creativity product/idea is considered novelty if the audiences agreed that it was a creative idea (Csikszenmihalyi, 2006; Amabile, 1996; Kharkhurin, 2014; Simonton, 2012).Therefore, novelty is the heart of a creative item (Weisberg, 2015; Jonge, Rietzschel \& Yperen, 2018; Ang, Lee \& Leong, 2007; Reio \& Choi, 2004, Zhou, Wang, Song \& Wu, 2017; Zhanetta, 2011). The reaction towards a novelty item is evident where it produced unexpectedness (Bruner, 1962), surprise (Haberland \& Dacin, 1992), unusualness (Jackson \& Messick, 1965), uniqueness (Kampylis \& Valtanen, 2011; Belch \& Belch, 2003; Chandralal \& Valenzuela, 2015), unpredictablility (Sharifian, 2014), or an immediate blow of eye (Parsons, 1969) in the receiver. Some researchers mentioned that novelty, described as unexpectedness or unpredictableness is an indicator of surprise (Lehnert, Till \& Carlson, 2013; Reisensein, 2000; Macedo \& Cardoso, 2000; Ortony, Clore \& Collins, 1994; Goolaup \& Nukoo, 2017).These characteristics of perceived creativity are described as neutral short-lived emotions (Reisenzein, Meyar \& Schutzwohl, 1996; Feldman, 1934; Mellers, Fincher, Drummond \& Bigony, 2012; Lindgreen \& Vanhamme, 2005; Foster \& Keane, 2015).

Based on the above explanations, perceived creativity is an important construct for this study because it is an indication of the presence of the creative item and the presence of this reaction behaviour in societies is subjective and outside the realm of rational (Nystrom, 2000) which current postmodernism societies need internal lack of balance in life, constantly require novelty in everyday leisure activities to prevent them for boredom in the process to achieve self-realization (Gonzalez-Cutre et al., 2016).Moreover, according to the literature, (e.g. extraordinary experience literatures in section 2.2.1), an interaction with an experience requires this reaction for its process of consumer brand engagement to occur, for this engagement construct consists of characteristic of intrinsic motivation explained in section 2.4. However, the study of this construct in social media e.g. Lee \& Hong, 2016; Tafesse, 2015; Syrdal \& Briggs, 2018 mostly focuses on social media engagement metrics of output behaviour of share, like or comment. So, the construct of perceived creativity plays a role of 
another underlying subjective behaviour that creates the process of consumer brand engagement in this study.

\subsection{Consumer Brand Engagement}

According to the English dictionary, 'engagement' refers to the period between a marriage proposal and the actual wedding, or partners entering into a contract (Stevenson, 2010). The first concept defined was used in the academic field of organizational behavior to refer to 'employee or job or personal engagement' which focused on investing one's intrinsic physical, cognitive and emotional values, when they attached these intrinsic values able to increase motivation to their job or company (Khan, 1990; Rich, Lepine \& Crawford, 2010; Schaufeli, 2013).This concept also started to blossom in other fields e.g. the field of education psychology named it 'student engagement' to refer to how students think, and their interests and behaviour at school (Fredricks, Blumnfeld \& Paris, 2004).

In the marketing field, the term was basically derived from exchange schools that were based on generic or social exchange (Shaw \& Jones, 2005) during the end stage of the service marketing management approach (Brodie et al. 2011; Sheth \& Parvatiyar, 1995a; Sheth \& Parvatiyar, 1995b; Javornik \& Mamdeli, 2013), with marketers agreeing that services are intangible and required exchange beyond profit to include exchange of resources of belief, feeling and energy of both parties, this led to the emergence of customer-seller relationships (Kotler, 1972; Palmatier et al., 2017) with the concept named 'co-production or relational engagement' (Heide \& John, 1990). Then later, Brodie et al. (2011) named it 'consumer engagement' which was defined as the psychological state that occurs with different consumer engagement levels of cognitive, emotional and behavioral in a context-dependent condition based on service dominant logic perspective. Hollebeek (2011b) named it 'customer brand engagement' which was defined as the level of the customer motivation by specific levels of cognitive, emotional and behavior activities during brand interactions from the social exchange perspective.

It was then the technological revolution gave rise to the full focus of relationship marketing (Palmatier et al., 2017) due to new possibilities for customers' empowerment and activities (Javornik \& Mamdeli, 2013). This word started to be actively used during internet era focus to have customers actively brand relationship is to have customers actively engage with frequently using the medium (Mollen \& Wilson, 2010). Then, when expressive social media arose, the first focus was on customer engagement behaviour with this concept defined as customer behavioural manifestations such as blogging, word of mouth, participation etc. resulting from motivational drivers (Van Doorm et al., 2010;Verhoef, Reinartz \& Krafft, 2010; Jaakkola \& Alexander, 2014). Picked up from the general context, Hollebeek, Glynn \& Brodie (2014) was the first person to define engagement in the social media context as 'consumer brand engagement' which defined it as a consumer positively valance of cognitive, emotional and behavioural during brand interaction. This was followed by Solem (2015) who defined consumer brand engagement concept as the customer's motivational and positive state of mind characterized by behavioural intentions, emotional and cognitive during brand interactions.

From then on, consumer brand engagement, as agreed by marketing researchers, is the only significant concept used as a metric for brand engagement in all contexts (Gambetti \& Graffigna, 2010) and most marketing researchers agreed that this concept was multidimensional consisted of mind, heart and hand in an expressive social media context (Hollebeek et al., 2014; Dessart, Veloutsou \& Thomas,2015; Solem, 2015) and in a general object or context (Brodie et al., 2011; Hollebeek 2011a; Hollebeek 2011b; Dwivedi, 2015). The mind-dimension which is also named cognitive engagement is described as thought processing (Hollebeek et al., 2014; Solem, 2016), and absorption (Dwivedi, 2015), and interest (Hollebeek, 2011b) of the consumer with the brand. The heart-dimension which is also named affective/emotional engagement is described as positive emotion (Hollebeek 2011a; Solem, 2016; Dessart et al., 2015), or positive related affect (Hollebeek et al. 2014) with the brand. The hand-dimension which is also named behavioural/behavioural intention engagement is described as the energy and time spent with the brand (Solem, 2015; Dwivedi, 2015).

On the other hand, some have argued that engagement of conative behavior is the consequences of dimension of cognitive and affective engagement (Malthouse \& Calder, 2011). This was proposed by Higgins (2006) where engagement is a motivational force of attraction. And recently, a researcher conducted a literature review that explained cognitive and affective as a kind of internal state response which was a motivational experience known as antecedent of engagement (Javornik \& Mamdeli, 2013) especially in online context suggested by Mollen \& Wilson (2010) who reviewed past literature of online context found that for example in a e-learning context stimulation promotes interest and desire to engage for continuous learning (Jones, 1998).

Based on the above, the roots of engagement are from extended relationship marketing (Brodie, Glynn \& Durme,2002) which is a relational construct its' dimension consists of characteristic of intrinsic motivation 
which is the process of pleasure and interest and later behavior that engages in the given activities with brand (Vallerand, 1997; Ryan \& Deci, 2000a; Ryan \& Deci, 2000b; Moore \& Diehl, 2019). However, there is lack of research study on the relationship of multidimensional consumer brand engagement to verify it as an intrinsic motivation (e.g. Hollebeek et al., 2014) to support that intrinsic motivation is able to increase user brand relationship activities (Ranasinghe \& Samarasinghe, 2019). Most studies focus on suitable content with social media engagement metric as mentioned in section 2.2.1.Hence, the study of the relationship within the multidimensional consumer brand engagement i.e. 'cognitive, affective, intentional' engagement enables us to capture the underlying process of behaviour (So et al., 2015).

\section{Research Framework and Hypotheses}

This research model consists of seven constructs as shown in figure 1.

According to literature, when an audience interfaces with an environment, interface preliminary information of the content will be presented to the audience and later will create an interface assessment or appraisal (Oh et al., 2015; Moors, Ellsworth, Scherer \& Frijda, 2013).Additionally, the creative literature, which is defined as that creative process produced through combinatory play (Zhanetta, 2011; Rothenberg, 1986) and brand literature described as combination of tangible and intangible of a product are considered to be creative (Kampylis \& Valtanen, 2011). Feeling theorists also believed that to have emotional projection we need to have subjective feeling of touch (Shouse, 2005; Whiting, 2009: Moors, 2009; Evers, Stock \& Ridder, 2010). Experiential content for this research consists of functional appeal, emotional appeal and vividness that are described as providing the users with experiences of pragmatic, feel and sense/aesthetic for the processing of individual preliminary information and then production of perceived creativity. Perceived creativity, the short-lived neutral emotion describes the assessment or appraisals of the experiential content with three hypotheses were proposed:

H1: Functional appeal is positively related to perceived creativity

$\mathrm{H} 2$ : Emotional appeal is positively related to perceived creativity

H3: Vividness is positively related to perceived creativity

Then, the interface assessment or appraisal shaped the process of engagement which begun with the intrinsic state of motivational behaviour of curiosity and interest (Oh et al., 2015; Moors et al., 2013). In the tourism, organization behaviour and artificial system literature supported that novelty behaviour plays an important role in building intrinsic motivation (Grant \& Berry, 2011; Toyama \& Yamada, 2012; Barto, Miroli \& Baldassame, 2013). From the psychology literature, novelty can keep one motivated with intrinsic rewards of emotion and thinking (Csikszentmihalyi \& Asakawa, 2016).Some explained this novelty behaviour as a neutral emotion is valance by emotions (Mellers, et al., 2012; Lindgreen \& Vanhamme, 2005; Foster \& Keane, 2015) which can be a good or bad (Lindgreen \& Vanhamme, 2005) which is the reflection of novelty behaviour. And some say that novelty behaviour can elicit an instinct of curiosity (Reisensein, 2000; Eelen, Rauwers, Wottrich, Voorveld \& Noort, 2016) of exploratory, interest and imagination(Reio \& Choi, 2004;Kidd \& Hayden, 2015) which some named 'knowledge emotion' (Silvia, 2005; Kashdan, Rosse \& Fincham, 2004). For this research, perceived creativity as the assessment or appraisal of the experiential content will shape the process of intrinsic state of engagement of cognitive engagement the curiosity behaviour and affective engagement the positive emotion and the two hypotheses were proposed:

H4: Perceived creativity is positively related to cognitive engagement

H5: Perceived creativity is positively related to affective engagement

According to organizational behavior and psychology literature, the intrinsic motivation construct consists of characteristics of a curiosity-based behavior and pleasure of emotion that is accompanied by a willingness of action (Ryan \& Deci, 2000a; Ryan \& Deci, 2000b; Gagne, 2014). The traditional media/website literature supported the process of cognitive and affective behaviors an internal response in reaching a person's response (Calder, Isaac \& Malthouse, 2016; Mollen \& Wilson, 2010). From the brain literature, the output behaviour response happens when a person is curious, and euphoria can increase dopamine in the brain which can heightened energy (Regan, 2011;Ostroff, 2016).The marketing literature also found that curiosity leads to behavior intention (Driessche, Vermeir, Pandelaere, 2013) and a brand passion promotes loyalty (Pouraza, Pare $\&$ Saniee, 2015). For this study, the behavioral intention engagement is the willingness to click on the social media button of like, share and comment. With that, the cognitive engagement and affective engagement can shape intention engagement with hypothesis proposed:

H6: Cognitive engagement is positively related to intentional engagement 
H7: Affective engagement is positively related to intentional engagement

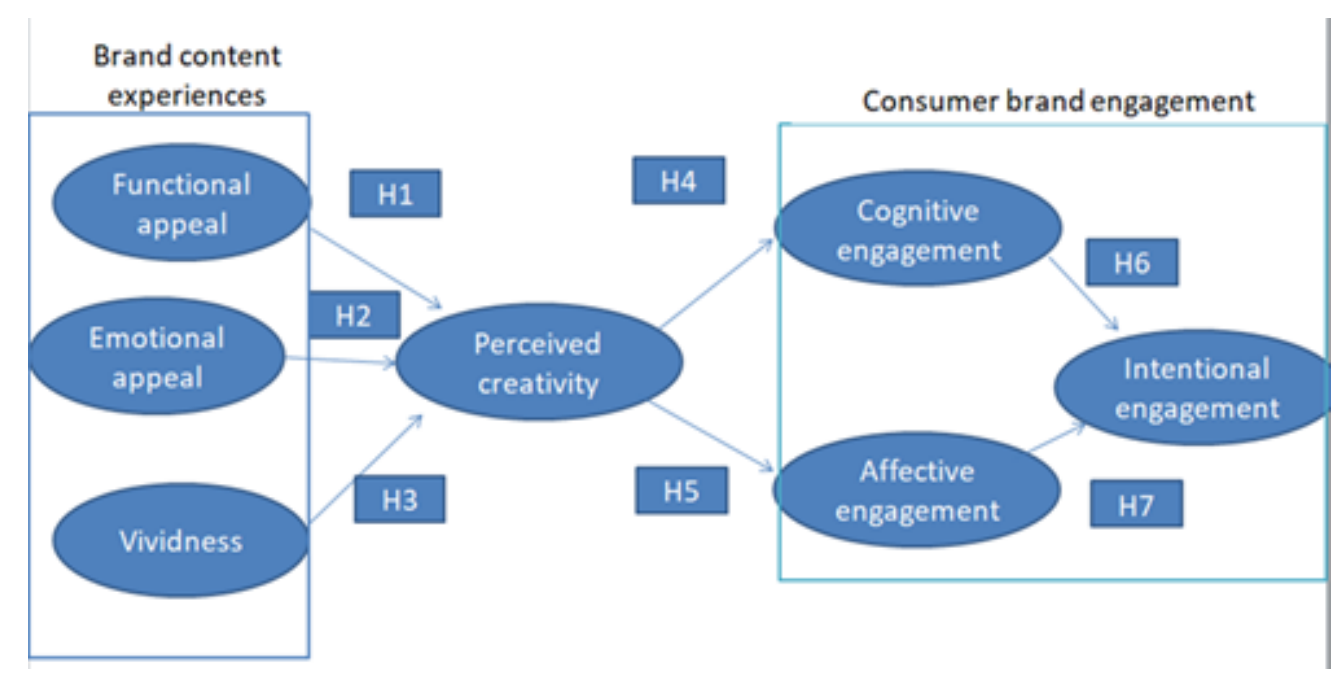

Figure 1. Research Model

\section{Research Method}

This research used a descriptive-explanatory approach to describe the baseline characteristics of a targeted population study and to study the relationships between a set of different variables (Saunders et al., 2009) with a one shot treatment (Malhotra, 2010). This one shot treatment has been widely used by marketing researchers to understand how a context or the evaluation of an object lead to user further responses (Vaughan, Beal \& Romaniuk, 2016; Taylor, Lewin \& Strutton, 2011), e.g. a retail experience (Chang, Eckman \& Yan, 2013), a Facebook brand still image as an advertisement response (Lee \& Hong, 2016) and a hotel social media site to evaluate user response (Leung, Bai \& Sathura, 2013). This is in accordance with the research focus for this study that aims to provide brand content experience assessed as creative that shapes the process of consumer brand engagement.

\subsection{Sampling}

Malaysia, with total population of 32.8 million (Statista, 2019a) has a 78\% social media penetration rate. Its penetration rate is ranked among the top global 4 (Kemp, 2019a) and Malaysian social media users are predicted to increase from 24.1 million in 2019 to 26.1 million by 2023 (Statista, 2019b).The sample used was 25-34 year old Malaysian active expressive social media societies who accessed expressive social media sites for at least 3 hours daily. This age group selected aim to represent person who were living in era of advancement in technologies (Ting, Lim, DeRun,Koh \& Sahdan, 2018) with the heaviest usage of expressive social media (Kemp, 2019b) and internet (Google Barometer, 2018). The population selected were also representative of the largest consumer segment (Dawn \& Thomas, 2013). It was therefore anticipated that the economy would later experience a shift in spending power to this age group over the next two decades (Nielsen, 2015; Ting et al., 2018).

The sample size used was based on 10 to 20 participants per estimated parameter as the sufficient sample for the statistical power analysis (Kline, 2016). So, for this research, (49 parameters x 15 participants) giving us a sample size of 735 participants. We however, recruited 750 participants to enhance the precision of the sampling outcome (Malhotra, Kim \& Patil, 2006).

The sampling technique was based on non-probability method because the sampling frame was challenging to define due to the unstructured nature of internet (Fricker, 2008) leads to an undefined population list of the online social network (Pina-Gracia\& Gu, 2013; Pina-Garcia, Gershenson \& Siqueiros-Gracia, 2016).So, a purposive sampling was used.

\subsection{Measurements}

Primary data was obtained using a two-part survey questionnaire.

The first part was used for pre-screening and to give an insight into the demographic characteristics and general behavior of the respondents. It had a total of 6 close-ended questions (i.e. age, gender, marital status, citizenship, type of expressive social site accessed each day, number of hours spent on these expressive social media sites 
daily) in a nominal scale.

In the second part, a stimulus was used as a treatment and 21 close-ended questions each with responses rated on 7-point Likert scale of extremely disagree to extremely agree, were used to capture the perceptions of the respondents. The treatment used was a still image from a Pinterest posting of an airline company named Cathay Pacific image as shown in appendix. The stimulus chosen for this study was measurable in each dimension of experiential content and creative criteria. First, the stimulus used a complementary colour i.e. 2 colours opposite the colour wheel i.e. blue (cold colour) and brown (warm colour) and created a high contrast in the still image, enlarged the number " 5 " on the center of the still image create an impact on the sense (Hauff, 2018; Bakar, Desa \& Mustafa, 2015) and the "text" in white colour to balance the vibrance of rich colours used in the still image (Imtza, 2016). Next, for the feel experience, brown colour indicates security and protection for the psychology of reliability, and blue colour is a social sensory colour favourable to all age groups and sexes indicate provides feeling of trust (Imtza, 2016;Rider, 2009; Donovan, Agarwala \& Hertzmann, 2011). The text \& image clearly stated "accessible five times a day" and provided flight-timing on the right-hand side corner which was pragmatic evidence of 5 daily flights.

For the creative criteria, this still image selected, had been identified as the best airline online campaign in an internet advertising competition based on its advertisement creativity, design and copywriting from expert judges (Internet Advertising Competition [IAC], 2016). The airline was the chosen brand stimuli because it had been praised for its relative fluency in applying expressive social media as platform to improve customer experience and building relationships makings it a leader in social care (Social Bakers Report, 2014; Koch \& Tritscher, 2017; NIIT Technologies, 2013).

The measurement items were adapted from related prior studies to align with the context of expressive social media. Experiential content consisted of three components i.e. functional appeal, emotional appeal and vividness. Functional appeal referred to the degree of information in the still image perceives as usable. This scale adapted from Taylor et al. (2011) with reliability of 0.87 had used as an informative scale in a general expressive social media context referenced by Cachero-Martinez \& Vaquez-Casielles (2017) pragmatic experience scale from the retail context that had a reliability $>0.7$ for slight correction of items to suit the usable experience. Emotional appeal referred to the extent to which users are able to have a feeling when perceiving the intangible of the brand content from a still image; the scale was adapted from Delgado-Ballester \& Sabiote (2015) mixture of emotions and feelings scale that had reliability 0.94 and referenced of Escalas \& Stern's (2003) feelings scale of a TV commercial that had a reliability 0.95 for slightly correction of items to suit the 'feel' experience. Finally, vividness referred to the degree to which a user was able to have a keen sight of the beauty of the content. This was adapted from Delgado-Ballester \& Sabiote's (2015) scale of sensory brand experience that had a reliability 0.88 . Perceived creativity construct is the degree to which individual evaluation of an experience produces novelty emotions; it has a scale of 0.903 and was adapted from Lee \& Hong's (2016) advertising creativity scale by dropping one of the items due to the item 'intriguing' belongs to curiosity behaviour.

Next, consumer brand engagement consisted of three dimensions with cognitive engagement referred to the degree to which an individual produced in depth instinct of curiosity and was adapted from Chang, Tseng, Liang \& Yan's(2013) scale which measures curiosity behaviour in English learning and has a reliability of 0.90 and Hollebeek et al.'s (2014) scale of cognitive processing in a LinkedIn site that has a reliability of 0.878 with item wording slight correction, affective engagement is the degree to which produces affectionate emotions and this was adapted from Hollebeek et al.'s (2014) scale that measures affect emotion in a LinkedIn site with a reliability of 0.830 and intentional engagement refers to activation of users brand activities and was adapted from the scale of Solem (2016) that measures spending of energy on a brand on Facebook and has a reliability of $>0.70$.

Using adapted scales with slight correction of item-wording to suit the construct and context had to have their validity retested for its psychometrics properties (Heggestad et al.2019). Therefore, scale content validity was conducted by 5 expert panels (Shrotryia \& Dhanda, 2019; Zamanzadeh et al., 2015) and pilot test conducted on 58 respondents (Viechtbauer et al. 2015).Additionally, exploratory factor analysis was conducted for parsimony to identify which item underlay which construct (Hair et al., 2006) and confirmatory factor analysis was performed to confirm the validity of the scale based on convergent and discriminant validity (Hair et al. 2014). Table 2 shows the finalized items of the scale.

\subsection{Data Collection}

An online self-administrated survey was conducted using Google Form tools. A link was sent to the respondents through expressive social media messaging sites to enable them to conveniently respond via a mobile telephone 
and laptop. Respondents completed the survey by clicking a mouse or keyboard to answer the questions that best represented their responses.

\section{Results}

\subsection{Pilot Test}

From the results of the pilot test, the Cronbach Alpha for the scale of FA was 0.953, EA was 0.965, V was 0.929, $\mathrm{C}$ was $0.903, \mathrm{CE}$ was 0.929 , AE was 0.934 and IE was 0.928 which showed the consistency of the items in each scale. The respondents rated the clarity of the measurement items on a 4- point Likert scale (from very unclear, unclear, clear, to very clear), and 56 respondents rated the questions as clear and very clear with only 2 respondents rated unclear. With that, indicating more than half of the respondents found the questions clear and therefore usable for the main survey.

\subsection{Pre-Test Analysis}

A total of 750 questionnaires were sent out, 740 usable responses were returned (response rate of $98.6 \%$ ), hence, non-response bias was not conducted (Roni, 2015). To minimize any potential common method variance in the data obtained from the self-reported survey with all the questions were collected in the same period of time using same method with the same sample (Podsakoff, MacKenzie \& Podsakoff, 2003), the common method variance test was performed to assess for common method bias using Herman single factor test in IBM SPSS with a result of $42.482 \%$ which is less than $50 \%$ indicating no bias was present. To enhance the validity of the results, we further conducted a common latent factor method in IBM AMOS and the results showed that delta values ranging from -0.064 to 0.035 which was less than 0.5 exhibited no bias (Levin, Quach \& Thaichon, 2019; Eichhorn, 2014).This indicated that the significance of the substantive relationship was not affected .

\subsection{Demographic Profile}

The respondents (25-34 years old Malaysian active expressive social media users) were mostly males and single. The majorities accessed expressive social media sites for 3 to 4 hours a day and were within the age group of 31-32 year-old. The expressive social media sites that was accessed daily by users was Facebook and most respondents logged in at least one account daily and with a minority logging in 4 accounts daily.

Table 1. Demographic Profile of the Sample Population

\begin{tabular}{|c|c|c|c|}
\hline Attribute & Categories & Frequency & Percentage $(\%)$ \\
\hline \multirow[t]{3}{*}{ Gender } & Male & 269 & 36.4 \\
\hline & Female & 226 & 30.5 \\
\hline & Prefer not to say & 245 & 33.1 \\
\hline \multirow[t]{5}{*}{ Age } & $25-26$ & 115 & 15.5 \\
\hline & $27-28$ & 122 & 16.5 \\
\hline & $29-30$ & 127 & 17.2 \\
\hline & $31-32$ & 223 & 30.1 \\
\hline & $33-34$ & 153 & 20.7 \\
\hline \multirow[t]{3}{*}{ Marital } & Single & 345 & 46.6 \\
\hline & Married & 137 & 18.5 \\
\hline & Prefer not to say & 258 & 34.9 \\
\hline \multirow{2}{*}{$\begin{array}{l}\text { Duration use of expressive } \\
\text { social media sites daily }\end{array}$} & 3- 4 hours & 599 & 80.9 \\
\hline & More than 4 hours & 141 & 19.1 \\
\hline \multirow[t]{16}{*}{ Accounts used daily } & $\mathrm{F}$ & 278 & 37.6 \\
\hline & I & 121 & 16.4 \\
\hline & $\mathrm{T}$ & 61 & 8.2 \\
\hline & $\mathrm{P}$ & 67 & 9.1 \\
\hline & $\mathrm{L}$ & 31 & 4.2 \\
\hline & $\mathrm{F} \& \mathrm{I}$ & 87 & 11.8 \\
\hline & $\mathrm{F}, \mathrm{I} \& \mathrm{~L}$ & 22 & 3.0 \\
\hline & $\mathrm{F} \& \mathrm{~L}$ & 12 & 1.6 \\
\hline & $\mathrm{F}, \mathrm{I} \& \mathrm{~T}$ & 17 & 2.3 \\
\hline & F,I,T \&L & 8 & 1.1 \\
\hline & P\&L & 4 & 0.5 \\
\hline & $\mathrm{I} \& \mathrm{~T}$ & 3 & 0.4 \\
\hline & $\mathrm{F} \& \mathrm{P}$ & 9 & 1.2 \\
\hline & $\mathrm{F}, \mathrm{P} \& \mathrm{I}$ & 5 & 0.7 \\
\hline & F,I,P \&L & 11 & 1.5 \\
\hline & $\mathrm{F}, \mathrm{T} \& \mathrm{~L}$ & 4 & 0.5 \\
\hline
\end{tabular}

Note. F: Facebook, I: Instagram, T: Twitter, P: Pinterest, L: LinkedIn 


\subsection{Measurement Model}

Reliability Analysis was conducted using IBM SPSS. The internal consistency of the scale was established using Cronbach's alpha measure (Reynaldo \& Santos, 1999). Exploratory factor analysis was conducted using IBM SPSS to explore the number of factors with high loads of items (Reio \& Shuck, 2014).This aimed to assist with the validity check of the scale for a cleaner measurement model for the purpose of confirmatory factor analysis (Watsons, 2017; Reio \& Shuck, 2014; Hair et al., 2014). The values of these measures are given in Table 2 Cronbach Alpha measures in this study were all above 0.70 indicating that the consistency of the set of items consistently loaded onto the same factor (Hair et al. 2003) and factor loadings above 0.6 indicate that no items need to be deleted (Hair et al., 2006).

Table 2. Results of Exploratory Factor Analysis \& Reliability Analysis

\begin{tabular}{|c|c|c|}
\hline Constructs /Items & $\begin{array}{l}\text { Factor } \\
\text { Loadings }\end{array}$ & $\begin{array}{l}\text { Cronbach } \\
\text { Alpha }\end{array}$ \\
\hline Functional appeal & & 0.848 \\
\hline FA1 The print content provides me with quality information. & 0.687 & \\
\hline FA2 The print content keeps me update with the information. & 0.730 & \\
\hline FA3 The print content provides a valuable source of information. & 0.850 & \\
\hline Emotional appeal & & 0.879 \\
\hline EA1 The print content induces certain feelings \& sentiments in me. & 0.771 & \\
\hline EA2 I have certain feelings towards the print content. & 0.798 & \\
\hline EA3 I experience feelings towards the print content. & 0.820 & \\
\hline Vividness & & 0.837 \\
\hline V1 The print content excites my senses. & 0.849 & \\
\hline V2 The print content appeals to my senses. & 0.694 & \\
\hline V3 The print content makes a strong impression to my senses. & 0.652 & \\
\hline Perceived creativity & & 0.704 \\
\hline $\mathrm{C} 1$ The print content is unique. & 0.735 & \\
\hline $\mathrm{C} 2$ The print content is out of ordinary. & 0.700 & \\
\hline C3 The print content differ from my expectations. & 0.777 & \\
\hline Cognitive Engagement & & 0.834 \\
\hline CE1 I am interested in this brand of social networking sites. & 0.771 & \\
\hline CE2 I have lot of imagination with this brand in social networking sites. & 0.726 & \\
\hline CE3 It leads me to explore more about this brand in social networking sites. & 0.801 & \\
\hline Affective Engagement & & 0.830 \\
\hline AE1 I feel happy when in contact with this brand in social networking sites. & 0.829 & \\
\hline AE2 I feel positive about this brand in social networking sites. & 0.711 & \\
\hline AE3 I feel pleased in relation to this brand in social networking sites. & 0.671 & \\
\hline Intentional Engagement & & 0.820 \\
\hline IE1 I try my best to frequently visit the brand in social networking sites. & 0.801 & \\
\hline IE2 I'm willing to have an active relationship with the brand in social networking sites. & 0.751 & \\
\hline IE3 I will put my full effort in supporting the brand at its social networking sites. & 0.748 & \\
\hline
\end{tabular}

Next, a confirmatory factor analysis was conducted using IBM AMOS to test the measurement model. Goodness of fit [GoF] test was tested using absolute fit indices [GFI=0.903; RMSEA $=0.067]$ and incremental fit indices $[\mathrm{CFI}=0.936$; TLI $=0.920]$. The overall fit for the measurement model was acceptable based on a conventional cut-off criteria of [GFI>0.90] (Hu \& Bentler, 1999), [RMSEA<0.08] (Hair et al., 2014), [CFI>0.90] (Hair et al., 2014) and [TLI>0.90] (Hu \& Bentler, 1999).

Then, the measurement model was assessed for its composite reliability and construct validity using IBM AMOS. Composite reliability [CR] values are shown in Table 3 and range from 0.714 to 0.850 with all exceeding 0.700 , suggesting good reliability (Fornell \& Larcker, 1981) and thus confirm that the measurement items consistently represented the same latent construct.

Construct validity was tested using convergent validity, discriminant validity and nomological validity rules. Results in Table 3 shows that factor loadings of each item exceeded the recommended 0.50 threshold (Hair et al., 2006) and the averages variances extracted [AVE] were above 0.50 indicating that they exceeded the threshold (Hair et al., 2014) with an exception of the AVE of construct $C$ that was 0.463 and therefore slightly below 0.50 . The items in the unfulfilled of construct $\mathrm{C}$ were not deleted because there was no problem with measurement model fit and the CR for construct $\mathrm{C}$ was higher than 0.60 which met the rule of thumb of Fornell \& Larcker (1981) and Chun, Wang, Wu \& Wan (2013). These results indicated that most of the latent variables in this 
research accounted for more than half of the explained variance in each indicator. For, discriminant validity, AVE obtained for each construct was larger than the squared inter construct correlation [SIC] showed in Table 4, this results showed that the measures of a construct were not highly correlated with other constructs indicating they maintain its' distinctive from each other (Hair et al., 2014).Lastly, nomological validity was used to test if correlations of the construct were positively significant which indicates that these constructs are positively related and supports that the proposed model make sense (Hair et al., 2014).The results of these assessment showed that the measurement model is valid.

Table 3. Results of Convergent Validity for the Measurement Model

\begin{tabular}{|c|c|c|c|}
\hline Construct/Item & Factor Loadings & $\mathrm{CR}$ & AVE \\
\hline Intentional Engagement & & 0.823 & 0.610 \\
\hline IE1 & 0.690 & & \\
\hline IE2 & 0.825 & & \\
\hline IE3 & 0.820 & & \\
\hline Affective Engagement & & 0.835 & 0.628 \\
\hline AE1 & 0.736 & & \\
\hline AE2 & 0.825 & & \\
\hline AE3 & 0.813 & & \\
\hline Cognitive Engagement & & 0.838 & 0.634 \\
\hline CE1 & 0.705 & & \\
\hline CE2 & 0.876 & & \\
\hline CE3 & 0.799 & & \\
\hline Perceived Creativity & & 0.714 & 0.463 \\
\hline $\mathrm{C} 1$ & 0.627 & & \\
\hline $\mathrm{C} 2$ & 0.844 & & \\
\hline $\mathrm{C} 3$ & 0.533 & & \\
\hline Vividness & & 0.847 & 0.650 \\
\hline V1 & 0.704 & & \\
\hline $\mathrm{V} 2$ & 0.872 & & \\
\hline V3 & 0.833 & & \\
\hline Emotional Appeal & & 0.882 & 0.713 \\
\hline EA1 & 0.813 & & \\
\hline EA2 & 0.889 & & \\
\hline EA3 & 0.830 & & \\
\hline Functional Appeal & & 0.850 & 0.655 \\
\hline FA1 & 0.858 & & \\
\hline FA2 & 0.844 & & \\
\hline FA3 & 0.718 & & \\
\hline
\end{tabular}

Table 4. Results of Discriminant Validity \& Nomological Validity for the Measurement Model

\begin{tabular}{|c|c|c|c|c|}
\hline Construct & Construct Relationship & AVE & SIC & $\mathrm{P}$ \\
\hline \multirow[t]{7}{*}{ Intentional Engagement [IE] } & & 0.610 & & \\
\hline & IE $<->$ FA & & 0.311364 & $* * *$ \\
\hline & $\mathrm{IE}<->\mathrm{C}$ & & 0.272484 & $* * *$ \\
\hline & $\mathrm{IE}<->\mathrm{AE}$ & & 0.438244 & $* * *$ \\
\hline & IE $<->$ EA & & 0.354025 & $* * *$ \\
\hline & $\mathrm{IE}<->\mathrm{V}$ & & 0.361201 & $* * *$ \\
\hline & $\mathrm{IE}<->\mathrm{CE}$ & & 0.451584 & $* * *$ \\
\hline \multirow[t]{7}{*}{ Affective Engagement [AE] } & & 0.628 & & \\
\hline & $\mathrm{AE}<->\mathrm{IE}$ & & 0.438244 & $* * *$ \\
\hline & $\mathrm{AE}<->\mathrm{FA}$ & & 0.380689 & $* * *$ \\
\hline & $\mathrm{AE}<->\mathrm{C}$ & & 0.310249 & $* * *$ \\
\hline & $\mathrm{AE}<->\mathrm{EA}$ & & 0.370881 & $* * *$ \\
\hline & $\mathrm{AE}<->\mathrm{V}$ & & 0.398161 & $* * *$ \\
\hline & $\mathrm{AE}<->\mathrm{CE}$ & & 0.451584 & $* * *$ \\
\hline \multirow[t]{7}{*}{ Cognitive Engagement [CE] } & & 0.634 & & \\
\hline & $\mathrm{CE}<->\mathrm{IE}$ & & 0.451584 & $* * *$ \\
\hline & $\mathrm{CE}<->\mathrm{FA}$ & & 0.342225 & $* * *$ \\
\hline & $\mathrm{CE}<->\mathrm{C}$ & & 0.231361 & $* * *$ \\
\hline & $\mathrm{CE}<->\mathrm{AE}$ & & 0.451584 & $* * *$ \\
\hline & $\mathrm{CE}<->\mathrm{EA}$ & & 0.341056 & $* * *$ \\
\hline & $\mathrm{CE}<->\mathrm{V}$ & & 0.3721 & $* * *$ \\
\hline
\end{tabular}




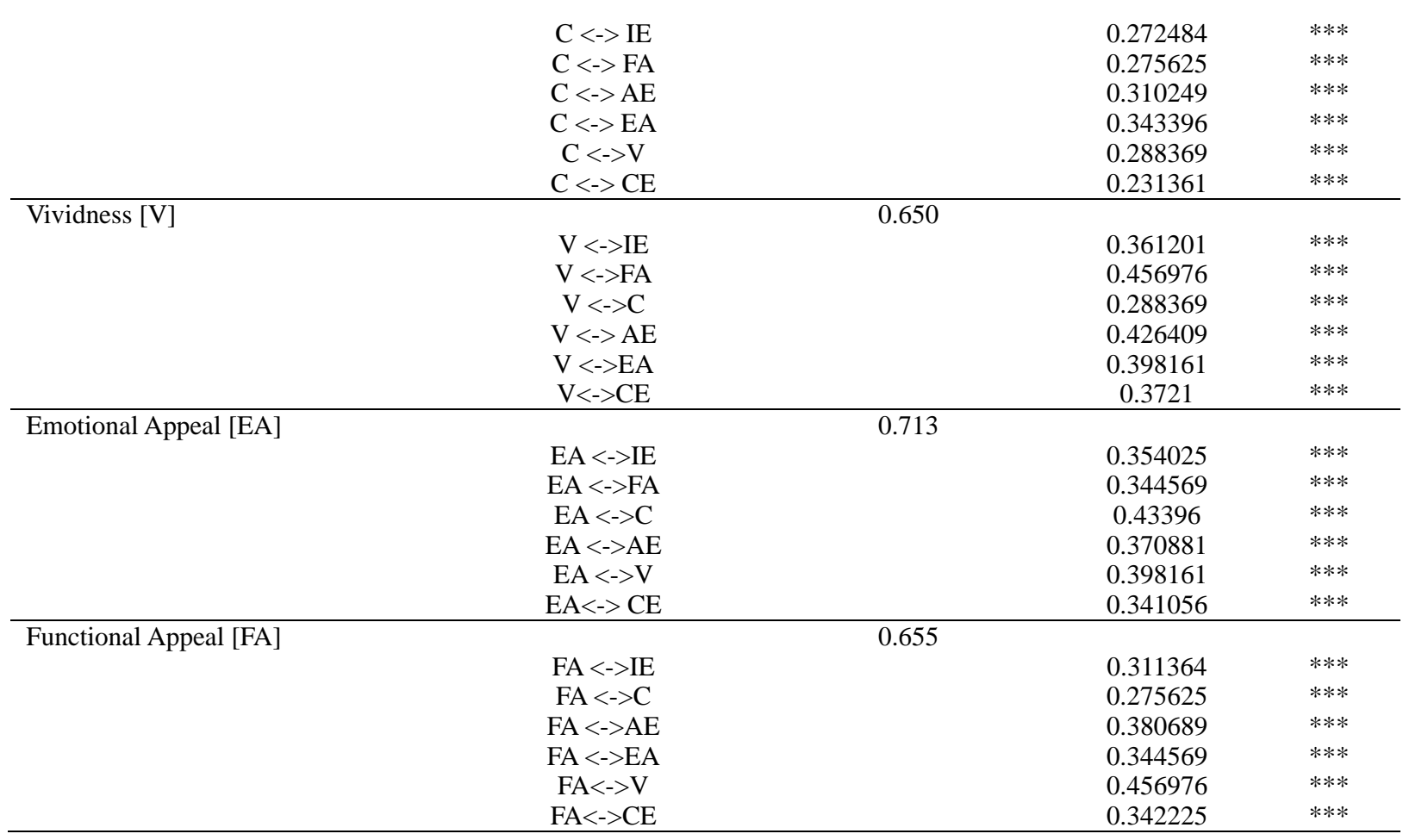

Lastly, a multi-collinearity check was conducted. The predictor variables of all the inner construct correlation [IC] were less than 0.85 with tolerance values of less than 1 and the variation inflation factor (VIF) values were within the range of 1.342 to 1.473 , VIF $<3$ provides proves that multicollinearity problem does not exist (Ho, 2014; O'brien, 2007) and indicates that there is no overlap of information across these independent variables. These results are shown in Table 5.

Table 5. Results of Multicollinearity of Predictors Variables

\begin{tabular}{lccc}
\hline Correlation & IC & Tolerance & VIF \\
\hline FA <-> EA & 0.587 & 0.701 & 1.427 \\
& & 0.679 & 1.473 \\
\hline FA<->V & 0.677 & 0.701 & 1.427 \\
& & 0.745 & 1.342 \\
\hline EA <->V & 0.631 & 0.679 & 1.473 \\
& & 0.754 & 1.342 \\
\hline
\end{tabular}

\subsection{Structural Model}

In this stage, when two-headed arrows from confirmatory factor analysis to become single-headed arrow to form structural model, the model fit will decrease due to specifics of the relationship (Hair et al., 2014). The GoF test was used to test the structural model fit and the estimated relationship within unobservable variables in a structural theory was evaluated (Hair et al., 2014).

The structural model was tested with result showing GoF indices of absolute fit [GFI=0.883; RMSEA=0.076] with threshold of [GFI>0.90] (Hu \& Bentler, 1999) and [RMSEA<0.08]. Hence, the result showed that the GFI indices were not in the acceptable range indicates that the estimated model doesn't reproduced data and explains the data well (Kline, 2016). The incremental fit indices [CFI $=0.913$; TLI $=0.898]$ had thresholds of [CFI>0.90] (Hair et al.,2014) and [TLI>0.90] (Hu \& Bentler,1999).TLI does not meet the requirement in its baseline model (Kilne, 2016). When there were model fit issues, structural model loadings were checked and it was found out that C3 measurement items had a low factor loading of 0.398 led to the model fit issues. Therefore, C3 measurements items were deleted to improve the quality of the latent construct. After $\mathrm{C} 3$ deletion, the structural model improved as shown in figure 2. The new structural model was subsequently assessed for its model fit using the GoF test. The GoF of absolute fit indices of the new structural model [GFI=0.904; RMSEA=0.070] and incremental fit indices $[\mathrm{CFI}=0.932$; $\mathrm{TLI}=0.920]$ both indices show that is within the acceptable cut-off ranges. 
Lastly to compare the fit of two models i.e. the old and new models, parsimonious fit indices were used. The new model with $[\mathrm{PNFI}=0.771$; $\mathrm{AIC}=836.033]$ had better parsimonious fit than the old model $[\mathrm{PNFI}=0.763$; $\mathrm{AIC}=1051.230$ ] respectively indicating fewness of freely estimated parameter relative to number of observations (Kline, 2016).

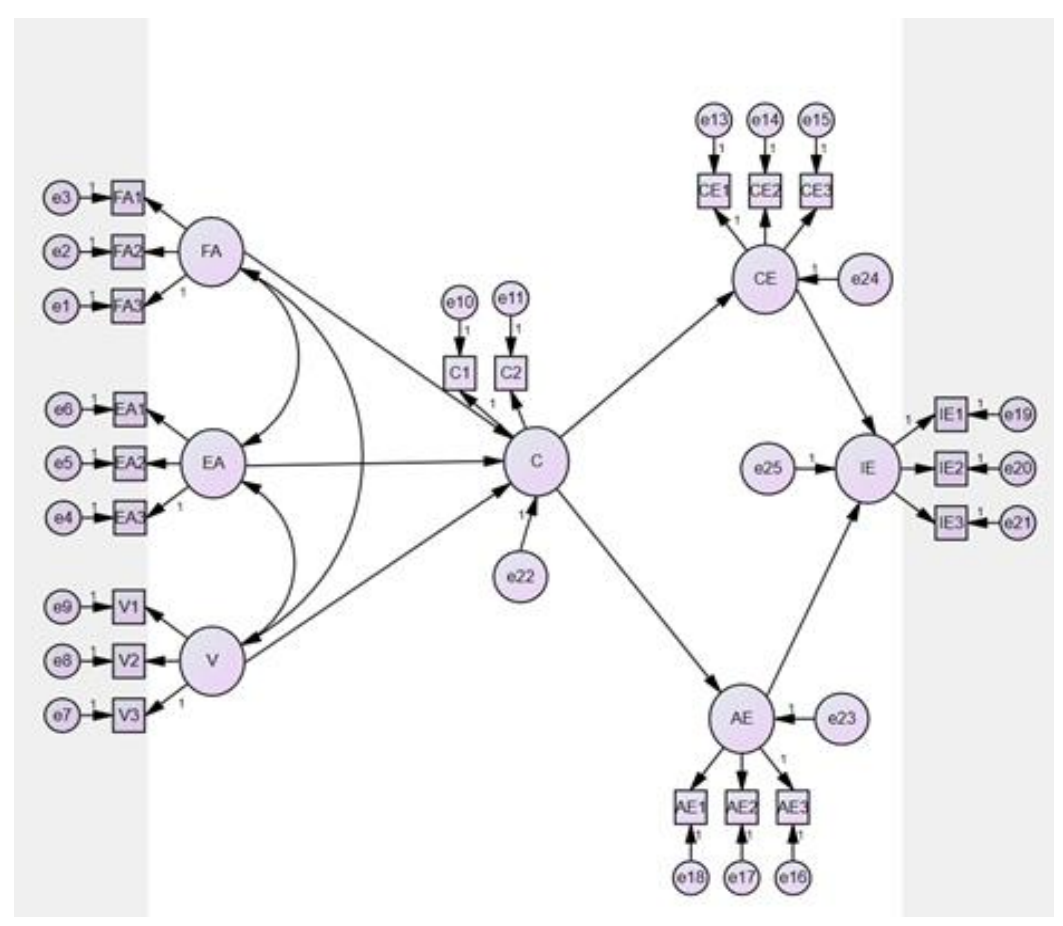

Figure 2. New Structural Model

Within the rules of structural equation modelling, residual error terms should be includes in any endogenous variables (Byrne, 2010). This was named square multiple correlation $\left(\mathrm{R}^{2}\right)$ for the purposes of providing an indication of the proportional (\%) of contribution of an exogenous construct in estimating endogenous construct. $\mathrm{R}^{2}$ values of $0.75,0.50$, or 0.25 for endogenous latent variables could be described as substantial, moderate, or weak respectively specifically in marketing research (Hair, Ringle \& Sarstedt, 2011). The explained variance $\left[\mathrm{R}^{2}\right]$ for e 22 was $77.4 \%$ this explained that $77.4 \%$ of the variance of support for perceived creativity $[C]$ was accounted for by the variance in functional appeal [FA], emotional appeal [EA] and vividness [V]. This indicated that it was able to effectively explain that a person's functional appeal, emotional appeal and vividness experience can substantially contribute to a person's perceived creativity behaviour. $\mathrm{R}^{2}$ for e 24 and e 23 showed that $69.2 \%$ of the variance for affective engagement $[\mathrm{AE}]$ and $59.5 \%$ of the variance of cognitive engagement [CE] were accounted for the variance in perceived creativity. This illustrated that perceived creativity substantially contributes to cognitive engagement $[\mathrm{CE}]$ and affective engagement. The model also accounted for $56.3 \%$ of the variance explained in intentional engagement [IE] implying that a person's curious and positive emotion behaviour meritoriously contributes to willingness to click a social media button. These ranges of $\mathrm{R}^{2}$ results also provide another validity indicator of the hypothetical structural model effectively matching the reality model (Lewis-Beck, Bryamn \& Liao, 2004; Baber, Thurasamy, Malik, Sadiq, Islam \& Sajjad 2016) and implies that the high variance explains in constructs provided preliminary explanations that the constructs hypothetical relationships are logical and possible.

Finally, the hypotheses of the path was tested; hypothetical model path relationships were all statistically significant at 0.001 level and strength of the relationship was above 0.02 varies from large, medium and small which provided clues that relationship strength was stable (Aiken \& West, 1991). From the values shown in Table 6, of all the paths in the improved structural model, the relationship of $\mathrm{C}->\mathrm{CE}$ and $\mathrm{C}->\mathrm{AE}$ was the most significantly impactful of all relationships. This means a novelty reaction can certainly produce curiosity and positive emotion behaviour in a human being. And, based on the evaluation of brand content experience as creative by an individual, displays that EA $>\mathrm{C}$ had the most significant strength when compared to $\mathrm{FA}->\mathrm{C}$ and 
V->C which implies that a content with feel experience has the most important role in creating novelty reaction whereas pragmatic experience and vividness plays a minor role in creating novelty reaction.

Table 6. Hypothesized Results of New Improved Structural Model

\begin{tabular}{|c|c|c|c|c|c|c|c|}
\hline & \multirow{2}{*}{$\begin{array}{l}\text { Hypothesized } \\
\text { Path }\end{array}$} & \multirow{2}{*}{$\begin{array}{l}\text { Standardized } \beta \\
\text { regression } \\
\text { weight }\end{array}$} & \multirow[t]{2}{*}{ C.R. } & \multirow[t]{2}{*}{$\mathrm{P}$} & \multicolumn{2}{|c|}{ Effect Size } & \multirow[t]{2}{*}{ Outcome } \\
\hline & & & & & Value & Interprets & \\
\hline H1. & FA->C & 0.289 & 5.585 & $* * *$ & 0.0730 & $\mathrm{~S}$ & Supported \\
\hline $\mathrm{H} 2$. & EA->C & 0.383 & 7.553 & $* * *$ & 0.2004 & M & Supported \\
\hline H3. & $\mathrm{V}->\mathrm{C}$ & 0.341 & 6.190 & $* * *$ & 0.1009 & $\mathrm{~S}$ & Supported \\
\hline $\mathrm{H} 4$. & $\mathrm{C}->\mathrm{CE}$ & 0.772 & 11.121 & $* * *$ & 1.4691 & $\mathrm{~L}$ & Supported \\
\hline H5. & C->AE & 0.832 & 11.988 & $* * *$ & 2.2468 & $\mathrm{~L}$ & Supported \\
\hline H6. & CE->IE & 0.416 & 7.852 & $* * *$ & 0.0588 & S & Supported \\
\hline $\mathrm{H} 7$. & AE->IE & 0.412 & 7.903 & $* * *$ & 0.0691 & $S$ & Supported \\
\hline
\end{tabular}

Note. The effect size recommended value with 0.02 to 0.14 is small [S], 0.15 to 0.34 is medium [M] and more than 0.35 is large [L], in addition, critical ratio [C.R.] $>1.96$ and $* * *$ significant at 0.001 level (two-tailed)

\section{Discussions \& Implications}

In the context of social networking sites, with a focus on consumer lack of engagement in brand activities, this research proposed that identifying brand content experiences perceived by user as creative would initiate the process of consumer brand engagement. The study showed that all the seven hypotheses were proven indicating that all the seven relationships within the constructs were supported. The summary of the GoF results also indicated the empirical results were consistent with the proposed research model. This means that active expressive social media users indeed behave like postmodern users more focused on subjective elements which in turn kick-starts an engagement relationship with a brand.

In this aspect, whereas the study of the content marketing framework in social networking sites still in exploratory phase, with this empirical study using experience dimension showed that results of the proposed $\mathrm{H} 1, \mathrm{H} 2$ and $\mathrm{H} 3$ had positive significant relationships with perceived creativity. This helped to contribute to a great extent to the theoretical foundation which constitutes of the components of functional appeal, emotional appeal and vividness that are the basic passive experience components that form a brand content experience and produce novelty emotion which is perceived creativity. Therefore, this confirms that to create passive engaging experience, the content components need to consist of functional appeal, emotional appeal and vividness which all play an important role in helping to fill the gap of identifying a suitable content marketing framework needed in brand posting.

Following this, results of $\mathrm{H} 4$ and $\mathrm{H} 5$ showed positive significant strong relationships that imply the active experience of curiosity and positive emotions of the expressive social media societies is elicited from novelty emotion. This confirms that novelty emotions are an important appraisal of the passive experience from functional appeal, emotional appeal and vividness that convert passive experience to active experience (curiosity and positive emotion). Because previous studies on content marketing expressive social media literature are mostly focused on studies of novelty (eg: Tafesse, 2015; Syrdal \& Briggs, 2018) with standard social media engagement metrics (share, like, comment) without studying the internal processes that provides the output behaviour. With the unpredictable behaviour of current societies (Batra \& Kazmi, 2008), a strong positive relationship of $\mathrm{H} 4$ \& $\mathrm{H} 5$ provide insight into marketing literature of what factors underlie the social media engagement metrics, the factors i.e. novelty emotion, curiosity and positive emotion which form the internal and intrinsic state that play utmost importance in contextualizing social media engagement metrics. Based on this, the research studies should more focus on the internal and intrinsic states of the user.

Finally $\mathrm{H} 6$ and $\mathrm{H} 7$ relationships in the research model, supported by the literature of psychology and organization behavior and results of $\mathrm{H} 6$ and $\mathrm{H} 7$ showed positive significant relationship and confirmed that multidimensional consumer brand engagement is an intrinsic motivation relation construct. This helped to enrich the concept of multidimensional consumer brand engagement and confirmed that multidimensional consumer brand engagement is an intrinsic psychological state of mind (i.e. cognitive engagement and affective engagement) that help stabilize the brand relationship, create frequent intentional engagement through clicking social media buttons of like, share and comment. This provides new knowledge to the literature i.e. the focus in social media marketing investment should not be focus on engagement rates. The results showed that the cognitive engagement and affective engagement are the ones that play a role in stabilizing social media 
engagement relationship to increase the current proportion of the expressive social media societies clicking and only in future, in enhancing probability of users becoming follower thereby building a long term consumer brand engagement kind of relationship

For the industry wise, this model is able to help a marketing communication manager to visualize a solution for a brand to break into the expressive social media environment so as to generate exposure of their brand posting by emphasizing strategies of creating content using a combination of pragmatic experience, feel experience and sense experience. Moreover, the research findings of $\mathrm{H} 2$ showed that it had strongest significant relationship when compared to $\mathrm{H} 1$ and $\mathrm{H} 2$ accorded to the industry player approaches to create content with more emotional appeal which then only followed by pragmatic and sense experience for an engaging creative content. Also, this study provided knowledge to industry players on how to bring the consumer closer to its nutshell for engagements activities by focusing on creating activities that stimulate users' intrinsic state engagement so that the users can develop an association with the brand during the consumption process opposed to focusing on engagement rate.

\section{Limitation \& Recommendations}

Although these research findings provide additional knowledge, but there were some limitations. Firstly, this was a cross-sectional study, therefore the research findings cannot explain the behavior of the respondents over of time. The adoption of purposive sampling method in this research also limits in generalization of study findings and making inference.

Future research may longitude this study and use probability sampling methods. This may also employ more than one or alternate brand still images or short videos meeting the criteria of experiential content as stimuli to test this research model. The research model can also be tested on a population from different age-groups of active expressive social media users and non-active expressive social media users.

\section{References}

Addis, M., \& Holbrook, M. B. (2001). On the conceptual link between mass customisation and experiential consumption: An explosion of subjectivity. Journal of Consumer Behaviour, 1(1), 50-66. https://doi.org/10.1002/cb.53

Addis, M., \& Podesta, S. (2005). Long life to marketing research: A postmodern view. European Journal of Marketing, 39(3/4), 386-412. https://doi.org/10.1108/03090560510581836

Aiken, L. S., \& West, S. G. (1991). Multiple regression: Testing and interpreting interactions. United States, US: Sage Publications Inc.

Amabile, T. M. (1996). Creativity in context: Update to the social psychology of creativity. Boulder, CO: Westview Press.

Amira, K. (2015). The creative concept and its role in advertising design. International Design Journal, 5(3), 1085-1090. Retrieved from

https://www.semanticscholar.org/paper/The-Creative-Concept-and-its-role-in-Advertising-Kadry/f36852529 909079009ea28f5ad86046e1baf8a22

Ang, S. H., Lee, H. Y., \& Leong, S. M. (2007). The ad creativity cube: Conceptualization and initial validation. Journal of Academy Marketing, 35, 220-232.

Appelbaum, U., \& Halliburton, C. (1993). How to develop international advertising campaigns that work: the example of the European food and beverage sector. International Journal of Advertising, 12(3), 223-241. https://doi.org/10.1080/02650487.1993.11104540

Arnould, E. J., \& Price, L. L. (1993). River magic: Extraordinary experience and the extended service encounter. Journal of Consumer Research, 20(1), 24-45. https://doi.org/10.1086/209331

Ashley, C., \& Tuten, T. (2015). Creative strategies in social media marketing: An exploratory study of branded social content and consumer engagement. Psychology \& Marketing, 32(1), 15-27. https://doi.org/10.1002/mar.2076

Baber, A., Thurasamy, R., Malik, I. M., Sadiq, B., Islam, S., \& Sajjad, M. (2016).Online word of mouth antecedents, attitude \& intention to purchase electronic products in Pakistan. Telematice \& Informatics, 33(2), 388-400. https://doi.org/10.1016/j.tele.2015.09.004

Bakar, A. M. H., Desa, M. M. A., \& Mustafa, M. (2015). Attributes for image content that attract consumers' attention to advertisements. Procedia-Social \& Behavioral Science, 195, 309-314. 
https://doi.org/10.1016/j.sbspro.2015.06.349

Barto, A., Miroli, M., \& Baldassame, G. (2013). Novelty or surprise? Hypothesis \& Theory Article, 4, 907. https://doi.org/10.3389/fpsyg.2013.00907

Batra, S. K., \& Kazmi, S. H. H. (2008).Consumer behaviour (2nd ed.). New Delhi: Excel Book.

Blasko, V. J., \& Mokwa, M. P. (1986). Creativity in advertising: A Janusian perspective. Journal of Advertising, 15(4), 43-72. https://doi.org/ 10.1080/00913367.1986.10673037

Blasko, V. J., \& Mokwa, M. P. (1988). Paradox, advertising \& the creative process. Paradox, advertising and the creative process. Current Issues and Research in Advertising, 11(1-2), 351-365. https://doi.org/10.1080/01633392.1988.10504938

Belch, E. G., \& Belch, A. M. (2003). Advertising and promotion: an intergrated marketing communications perspective 6th edition. New York, NY: McGraw-Hill.

Bloomstein, M. (2012). Content strategy at work. Real world stories to strengthen every interactive project. United States, US: Morgan Kauffmann.

Bouagina, J. D., \& Triki, A. (2014). From postmodernism to postmodern consumer: The impact on the consumption theory. Postmodern Openings, 5(2), 99-117. https://doi.org/10.18662/po/2014.0502.07

Bowden, J. L. H. (2009). The process of customer engagement: A conceptual framework. Journal of Marketing Theory \& Practice, 17(1), 63-74. https://doi.org/10.2753/MTP1069-6679170105

Brakus, J., Schmitt, B. H., \& Zarantonello, L. (2009). Brand experience: What is it? How is it measured? Does it affect loyalty? Journal of Marketing, 73(3), 52-68. https://doi.org/10.1509/jmkg.73.3.52

Bray, J. P. (2008). Consumer behaviour theory: approaches and models. Discussion Paper. United Kingdom, UK: Bournemouth University Research Online. Retrieved from http://eprints.bournemouth.ac.uk/10107/1/Consumer_Behaviour_Theory_Approaches_\%26_Models.pdf

Brodie, R. J., Glynn, M. S., \& Durme, J. V. (2002). Towards a theory of marketplace equity. Integrating branding and relationship thinking with financial thinking. Marketing Theory, 2(1), 5-28. https://doi.org/10.1177/147059310200200101

Brodie, R. J., Hollebeek, L. D., Juric, B., \& Ilic, A. (2011). Customer engagement: Conceptual domain, fundamental propositions, and implications for research. Journal of Service Research, 14(3), 252-271. https://doi.org/10.1177/1094670511411703

Brodie, R. J., Ilic, A., Juric, B., \& Hollebeek, L. (2013). Consumer engagement in a virtual brand community: an exploratory analysis. Journal of Business Research, 66(1), 105-114. https://doi.org/10.1016/j.jbusres.2011.07.029

Bruner, J. (1962). The new educational technology. American Behavioral Scientist, 6(3), 5-7. https://doi.org/10.1177/000276426200600302

Buckley, W. K. (1989). Mechanical man. John Broadus Watsons \& the beginnings of behaviourism. New York: The Guilford Press.

Bujisic, M., Bilgihan, A., \& Smith, S. (2015). Relationship between guest experience, personality characteristics, and satisfaction: Moderating effect of extraversion and openness to experience. Tourism Analysis, 20(1), 25-38. https://doi.org/10.3727/108354215X14205687167509

Cachero-Martinez, S., \& Vazquez-Casielles, R. (2017). Stimulating curiosity and consumer experience in a retailer. American Journal of Industrial and Business Management, 7(4), 473-486. https://doi.org/10.4236/ajibm.2017.74034

Calder, B. J., Malthouse, E. C., \& Schaedel, U. (2009). An experimental study of the relationship between online engagement and advertising effectiveness. Journal of Interactive Marketing, 23, 321-221. https://doi.org/10.1016/j.intmar.2009.07.002

Calder, B., Isaac, M. S., \& Malthouse, E. (2016). How to capture consumer experiences: a context specific approach to measuring engagement. Journal of Advertising Research, 56(1), 1-14. https://doi.org/10.2501/JAR-2015-028

Carbone, L. P., \& Haeckel, S. H. (1994). Engineering customer experiences. Marketing Management, 3(3), 8-19. Retrieved from https://www.scirp.org/(S(vtj3fa45qm1ean45vvffcz55))/reference/ReferencesPapers.aspx?ReferenceID=138 
964

Celsi, R. L., Rose, R. L., \& Leigh, T. W. (1993). An exploration of high-risk leisure consumption through skydiving. Journal of Consumer Research, 20(1), 1-23. https://doi.org/10.1086/209330

Chandralal, L., \& Valenzuela, F. R. (2015). Memorable tourism experiences: Scale development. Contemporary Management Research, 11(3), 291-310. https://doi.org/10.7903/cmr.13822

Chang, C. C., Tseng, K. H., Liang, C., \& Yan, C. (2013). The influence of perceived convenience and curiosity on continuance intention in mobile English learning for high school students using PDAs. Journal Technology, Pedagogy and Education, 22(3), 373-386. https://doi.org/10.1080/1475939X.2013.802991

Chang, H. J., Eckman, M., \& Yan, R. N. (2013). Application of the stimulus-organism-response model to the retail environment: the role of hedonic motivation in impulse buying behaviour. The International Review of Retail, Distribution \& Consumer Research, 21(3), 233-249. https://doi.org/10.1080/09593969.2011.578798

Chang, P. L., \& Chieng, M. H. (2006). Building consumer-brand relationship: A cross-cultural experiential view. Psychology \& Marketing, 23(11), 927-959. https://doi.org/10.1002/mar.20140

Chun, H., Wang, Y., Wu, W. T., \& Wan, P. A. (2013). An empirical analysis of the antecedents and performance consequences of using the moodle platform. International Journal of Information and Education Technology, 3(2), 217-221. https://doi/org/10.7763/IJIET.2013.V3.267

Clarke, J. (2013). Experiential aspects of tourism gift consumption. Journal of Vacation Marketing, 19(1), $75-87$. https://doi.org/10.1177/1356766712461406

Cohen, D. A. (2014). The hidden forces behind the obesity epidemic \& how we can end it. US: Rand Corporation.

Content Marketing Institute [CMI]. (2016). Definition of content marketing. Retrieved from http://contentmarketinginstitute.com/2016/11/content-marketingdefinitions

Coursaris, C. K., Osch, W. V., \& Balogh, B. A. (2016). Informing brand messaging strategies via social media analytics. Online Information Review, 40(1), 6-24. https://doi.org/10.1108/OIR-02-2015-0062

Cova, B., \& Dalli, D. (2009). Working consumers: The next step in marketing theory? Marketing Theory, 9(3), 315-339. https://doi.org/10.1177/1470593109338144

Cova, B. (1996). What postmodernism means to marketing managers. European Management Journal, 14(5), 494-499. https://doi.org/10.1016/0263-2373(96)00043-6

Csikszentmihalyi, M., \& Asakawa, K. (2016). Universal and cultural dimensions of optimal experiences. Japanese Psychological Research, 58(1), 4-13. https://doi.org/10.1111/jpr.12104

Csikszentmihalyi, M. (2006). A systems perspective on creativity in creative management \& development. California: Sage Publication.

Cvijkj, I. P., \& Michahelles, F. (2013). Online engagement factors on Facebook brand pages. Social Network Analysis and Mining, 3(4), 843-861. https://doi.org/10.1007/s13278-013-0098-8

Dawn, B. V., \& Thomas, L. P. (2013). Generation Y values and lifestyle segments. Journal of Consumer Marketing, 30(7), 597-606. https://doi.org/10.1108/JCM-07-2013-0650

De Vries, L., Gensler, S., \& Leeflang, P. S. H. (2012). Popularity of brand posts on brand fan pages: an investigation of the effects of social media marketing. Journal of Interactive Marketing, 26(1), 83-91. https://doi.org/10.1016/j.intmar.2012.01.003

Delgado-Ballester, E., \& Sabiote, F. E. (2015). Brand experimental value verses brand functional value: which matters more for the brand? European Journal of Marketing, 49(11/12), 1857-1879.

Dessart, L., Veloutsou, C., \&Thomas, A. M. (2015). Consumer engagement in online brand communities: A social media perspective. Journal of Product \& Brand Management, 24(1), 28-42. https://doi.org/10.1108/JPBM-06-2014-0635

Devitt, J. (2017). What gives poetry its aesthetic appeal? New research has well-versed answer. New York University. Retrieved From

https://www.nyu.edu/about/news-publications/news/2017/november/what-gives-poetry-its-aesthetic-appeal-new-research-has-well-ve.html

Donna, L. H., \& Marek, F. (2010). Can you measure the ROI of your social media marketing. MIT Slogan 
Management Review, 52(1), 41-49. Retrieved from

https://sloanreview.mit.edu/article/can-you-measure-the-roi-of-your-social-media-marketing/

Donovan, P. O., Agarwala, A., \& Hertzmann, A. (2011). Color compatibility from large datasets. Association For Computing Machinery, 63, 1-12. https://doi.org/10.1145/1964921.1964958

Driessche, L. V. D., Vermeir, I., \& Pandelaere, M. (2013). The curious case of curiosity: unpleasant advertising and curiosity. In G. Cornellissen, E. Reutskaja, \& A. Valenzuela, European Advances in Consumer Research, $10,340-340$.

Duhigg, C. (2012). The power of habit: why we do what we do in life and business. New York, NY: Random House.

Duhring, L. (2017). The history of marketing thought. Reassessing the relationship between marketing \& public relations. Spain: Springer.

Dwivedi, A. (2015). A higher-order model of consumer brand engagement and its impact on loyalty intentions. Journal of Retailing \& Consumer Services, 24, 100-109. https://doi.org/10.1016/j.jretconser.2015.02.007

Eelen, J., Rauwers, F., Wottrich, V. M., Voorveld. H. A., \& Noort, G. (2016). Consumer responses to creative media advertising: A literature review in advertising in new formats and media: current research and implications for marketers. UK: Emerald Group Publishing.

Eichhorn, B. R. (2014). Common method variance techniques. Cleveland State University, US.

Escalas, E. J., \& Stern, B. B. (2003). Sympathy \& empathy: emotional responses to advertising dramas. Journal of Consumer Research, 29, 556-578. https://doi.org/10.1086/346251

European Society for Opinion and Marketing Research [Esomar]. (2016). Revolutionising Asia. 3 Key Trends in Social Media. Retrieved from https://www.surveysampling.com/site/assets/files/2609/revolutionising_asia3_key_trends_in_social_media. pdf

Evans, D., \& McKee, J. (2010). Social media marketing: the next generation of business engagement. US: Sybex.

Evers, C., Stock, F. M., \& Ridder, D. (2010). Feeding your feelings: Emotion regulation strategies and emotional eating. Personality and Social Psychology Bulletin, 36(6), 792-804. https://doi.org/10.1177/0146167210371383

Feldman, R. V. (1934). The metaphysics of wonder and surprise. Philosophy, 9(34), 209-213. Retrieved from https://www.jstor.org/stable/3746611

Firat, F. A., Dholakia, N., \& Venkatesh, A. (1995). Marketing in a postmodern world. European Journal of Marketing, 29(1), 40-56. https://doi.org/10.1108/03090569510075334

Forlani, F., Pencarelli, T., \& Buratti, A. (2018). The experience logic as new perspectives for marketing management from theory to practical applications in different sectors. Italy: Springer International Series Advanced Management Studies.

Fornell, C., \& Larcker, D. (1981). Evaluating structural equation models with unobservable variables \& measurement error. Journal of Marketing Research, 18(1), 39-50. https://doi.org/ 10.2307/3151312

Fornerino, M., Guizon-Helme, A., \& Gotteland, D. (2008). Movie consumption experience and immersion: impact on satisfaction. Recherche et Applications En Marketing (English Edition), 23(3), 93-110. https://doi.org/10.1177/205157070802300306

Foster, M. I., \& Keane, M. T. (2015). Why some surprises are more surprising than others: surprise as a metacognitive sense of explanatory difficulty. Cognitive Psychology, 81, 74-116. https://doi.org/10.1016/j.cogpsych.2015.08.004

Frankl, E. V., \& Batthyanay, A. (2010). The feeling of meaninglessness. a challenge to psychotherapy and philosophy. Press of United States: Marquette University.

Fredricks, J. A., Blumenfeld, P. C., \& Paris, A. H. (2004). School engagement: potential of the concept, state of the evidence. Review of Educational Research, 74(1), 59-109. https://doi.org/10.3102/00346543074001059

Fricker, R. D. (2008). Sampling methods for web \& email surveys. In N. Fielding, R. M. Lee, \& G. Blank, The Sage Handbook of Online Research Methods, 195-217. 
Gagne, M. (2014). The oxford handbook of work engagement, motivation, and self-determination theory. Oxford Handbooks Online. https://doi.org/10.1093/oxfordhb/9780199794911.001.0001

Gambetti, R. C., \& Graffigna, G. (2010). The concept of engagement A systematic analysis of the ongoing marketing debate. International Journal of Market Research, 52(6), 801-826. https://doi.org/10.2501/S1470785310201661

Gensler, S., Volckner, F., Liu-Thompkins, Y., \& Wiertz, C. (2013). Managing brands in the social media environment. Journal of Interactive Marketing, 27, 242-256. https://doi.org/10.1016/j.intmar.2013.09.004

Gentile, C., Spiller, N., \& Noci G. (2007). How to sustain the customer experience: an overview of experience components that co-create value with the customer. European Management Journal, 25(5), 395-410. https://doi.org/10.1016/j.emj.2007.08.005

Gial, F. G., Zhang, J., Paul, J., \& Giala, N. G. (2018). The role of self-determination theory in marketing science: an intergrative review and agenda for research. European Management Journal, 37(1), 29-44. https://doi.org/10.1016/j.emj.2018.10.004

Gilmore, J. H., \& Pine, J. B. (1998). Welcome to experience economy. Harvard Business Review. Retrieved from https://hbr.org/1998/07/welcome-to-the-experience-economy

Goldenberg, J., Mazursky, D., \& Solomon, S. (1999). The fundamental templates of quality ad. Marketing Science, 18(3), 333-351. https://doi.org/10.1287/mksc.18.3.333

Gonzalez-Cutre, D., Sicilia, A., Sierra, A., Ferriz, R., \& Hagger, M. S. (2016). Understanding the need for novelty from the perspective of self-determination theory. Personality \& Individual Differences, 102, 159-169. https://doi.org/10.1016/j.paid.2016.06.036

Google Barometer. (2018). Consumer barometer of Google. Retrieved from https://www.consumerbarometer.com/en/insights/?countryCode=MY

Goolaup, S., \& Nukoo, R. (2017). Developing a theory of surprise from travelers' extraordinary food experiences. Journal of Travel Research, 1-14. https:// doi.org/10.1177/0047287517691154

Grant, A. M., \& Berry, J. W. (2011). The necessity of others is the mother of invention: intrinsic and prosocial motivations, perspective taking, and creativity. Academy of Management Journal, 54(1), 73-96. https://doi.org/10.5465/AMJ.2011.59215085

Ha, H. Y., \& Perks, H. (2005). Effects of consumer perceptions of brand experience on the web: brand familiarity, satisfaction and brand trust. Journal of Consumer Behaviour, 4(6), 438-452.

Haberland, G. S., \& Dacin, P. A. (1992). The development of a measure to assess viewers' judgments of creativity of an advertisement: A preliminary study. Association for Consumer Research, 19(1), 817-825. Retrieved from https://www.acrwebsite.org/volumes/7397/volumes/v19/NA-19

Hair, J. F., Ringle, C. M., \& Sarstedt, M. (2011). PLS-SEM: indeed a silver bullet. Journal of Marketing Theory and Practice, 19(2), 139-151. https://doi.org/10.2753/MTP1069-6679190202

Hair, J. F., Black, C. W., Babin, J. B., \& Anderson, R. E. (2014). Multivariate data analysis. USA: Pearson New International Edition.

Hair, J. F., Anderson, R. E., Tatham, R. L., \& Black, W. C. (2006). Multivariate data analysis. New Jersey: Prentice Hall.

Hair, J. F., Babin, B., Money, A. H., \& Samouel, P. (2003). Essential of business research methods. USA: John Wiley \& Sons.

Halberstam, D. (1993). The fifties: A cultural history. United States, US: Ballantine Book.

Hamouda, M. (2012). Postmodernism \& consumer psychology: Transformation or break? International Journal of Academic Research in Business, 2(1), 96-117.

Harker, J. M., \& Egan, J. (2010). The past, present and future of relationship marketing. Journal of Marketing Management, 22(1-2), 215-242. https://doi.org/10.1362/026725706776022326

Hauff, A. (2018). CoSchedule: Colour Psychology Marketing. Retrieved from https://coschedule.com/blog/color-psychology-marketing/

Heggestad, E. D., Scheaf, J. D., Banks, G. C., Hausfeld, M. M., Tonidandel, S., \& Williams, E. B. (2019). Scale adaptation in organizational science research: A review \& best-practice recommendations. Journal of 
Management, 45, 2596-2627.

Heide, J. B., \& John, G. (1990). Alliance in industrial purchasing: The determinants of joint action in buyer-supplier relationships. Journal of Marketing Research, 27(1), 24-36.

Higgins, E. T. (2006). Value from hedonic experience \& engagement. American Psychological Association, 113(3), 439-460. https://doi.org/10.1037/0033-295X.113.3.439

Hirvijarvi, F. (2017). Viral marketing and content forwarding on social media: outlining the key elements behind successful viral content creation (Unpublished degree's thesis). Arcada Business School, Finland. Retrieved from https://pdfs.semanticscholar.org/a141/8f5686cdc45c96e0cdf3fd4c2c7a14bdc0a0.pdf

Ho, R. (2014). Handbook of univariate \& multivariate data analysis with IBM SPSS (2nd ed.). Florida: CRC Press.

Hollebeek, L. (2011b). Exploring customer brand engagement: Definition and themes. Journal of Strategic Marketing, 19(7), 555-573. https://doi.org/10.1080/0965254X.2011.599493

Hollebeek, L. D. (2011a). Demystifying customer brand engagement: Exploring the loyalty nexus. Journal of Marketing Management, 27(7-8), 785-807. https://doi.org/ 10.1080/0267257X.2010.500132

Hollebeek, L. D., Glynn, M. S., \& Brodie, R. J. (2014). Consumer brand engagement in social media: Conceptualization, scale development and validation. Journal of Interactive Marketing, 28, 149-165. https://doi.org/10.1016/j.intmar.2013.12.002

Hollebeek, L. D., \& Macky, K. (2019). Digital content marketing's role in fostering consumer engagement, trust \& value: Framework fundamental proposition \& implications. Journal of Interactive Marketing, 45, 27-41. https://doi.org/10/1016/i.intmar.2018.07.003

Holliman, G., \& Rowley, J. (2014). Business to business digital content marketing: Marketers' perceptions of best practice. Journal of Research in Interactive Marketing, 8(4), 269-293. https://doi.org/10.1108/JRIM-02-2014-0013

Hongxia, Z. J., Sun, F. L., \& John, G. K. (2014). Be rational or be emotional: Advertising appeals, service types and consumer responses. European Journal of Marketing, 48(11/12), 2105-2126. https://doi.org/10.1108/EJM-10-2012-0613

Hosany, S., \& Witham, M. (2010). Dimensions of cruisers' experiences, satisfaction, and intention to recommend. Journal of Travel Research, 49(3), 351-364. https://doi.org/10.1177/0047287509346859

Hu, L., \& Bentler, P. M. (1999). Cutoff criteria for fit indexes in covariance structure analysis: Conventional criteria versus new alternatives. Structural Equation Modeling: A Multidisciplinary Journal, 6(1), 1-55. https://doi.org/10.1080/10705519909540118

Imtza, S. (2016). The psychology behind web design. McMaster University, Ontoria.

Internet Advertising Competition [IAC]. (2016). Best airline award. Retrieved from http://www.iacaward.org/iac/winners_detail.asp?yr=all\&award_level=best\&category=Airline

Jaakkola, E., \& Alexander, M. (2014). The role of customer engagement behavior in value co-creation a service system perspective. Journal of Service Research, 17(3), 247-261. https://doi.org/10.1177/1094670514529187

Jackson, P. W., \& Messick, S. (1965). The person, the product and the response: Conceptual problems on the assessment of creativity. Journal of Personality, 33(3), 309-329. https://doi.org/10.1111/j.1467-6494.1965.tb01389.x

Jacoby, J., \& Morrin, M. (2015) .Consumer psychology. International Encyclopedia of the Social \& Behavioral Sciences, 738-743. https:// doi.org/10.1016/B978-0-08-097086-8.22004-7

Jahn, B., \& Kunz, W. (2012). How to transform consumers into fans of your brand. Journal of Service Management, 23(3), 344-361. https://doi.org/10.1108/09564231211248444

Javornik, A., \& Mamdelli, A. (2013). Research categories in studying customer engagement. Conference Academy of Marketing, 1-12. Cardiff.

Jefferson, S., \& Tanton, S. (2013). Valuable content marketing: How to make quality content the key to your business success. London: Kogan Page.

Jones, M. G. (1998). Creating electronic learning environments: Games, flow, and the user interface. 
Proceedings Association for Educational Communications and Technology, 1-12.

Jonge, K. M. M., Rietzschel, E. F., \& Yperen, N. (2018). Stimulated by novelty? The role of psychological needs and perceived creativity. Personality \& Social Psychology Bulletin, 44(6), 851-867. https://doi.org/10.1177/0146167217752361

Kampylis, P., \& Valtanen, J. (2011). Redefining creativity: Analyzing definitions, collocations, and consequences. Journal of Creative Behavior, 44(3), 191-214. https://doi.org/10.1002/j.2162-6057.2010.tb01333.x

Kaplan, M. A., \& Haenlein, M. (2010). Users of the world, unite! The challenges and opportunities of social media. Businsess Horizons, 53(1), 59-68. https://doi.org/10.1016/j.bushor.2009.09.003

Kashdan, T. B., Rose, P., \& Fincham, F. D. (2004). Curiosity \& exploration: Facilitating positive subjective experience \& personal growth opportunities. Journal of Personality Assessment, 82(3), 291-305. https://doi.org/ 10.1207/s15327752jpa8203_05

Kemp, S. (2019a). Digital 2019: Global internet use accelerates. Retrieved from https://wearesocial.com/blog/2019/01/digital-2019-global-internet-use-accelerates

Kemp, S. (2019b). Digital 2019: Malaysia. Retrieved from https://www.slideshare.net/DataReportal/digital-2019-malaysia-january-2019-v01

Kennedy, A. K., \& Sommerfeldt, E. J. (2015). A postmodern turn for social media research: Theory and research directions for public relations scholarship. Atlantic Journal of Communication, 23, 31-45. https://doi.org/10.1080/15456870.2015.972406

Khan, W. A. (1990). Psychological conditions of personal engagement and disengagement at work. Academy of Management Journal, 33(4), 692-724. https://doi.org/10.5465/256287

Kharkhurin, A. V. (2014). Creativity 4in1: Four-criterion construct of creativity. Creativity Research Journal, 26(3), 338-352. https://doi.org/10.1080/10400419.2014.929424

Kidd, C., \& Hayden, B. Y. (2015). The psychology and neuroscience of curiosity. Neuron, 88(3), 449-460. https://doi.org/10.1016/j.neuron.2015.09.010

Kim, Y., Kang, M., Choi, S. M., \& Sung, Y. (2016). To click or not to click? Investigating antecedents of advertisement clicking on Facebook. Social behavior and personality. An International Journal, 44(4), 657-667. https://doi.org/10.2224/sbp.2016.44.4.657

Kim, K., \& Cheong, Y. (2011). Creative strategies of super bowl commercials 2001-2009: An analysis of message strategies. International Journal of Sports Marketing and Sponsorship, 13(1), 2-17. https://doi.org/10.1108/IJSMS-13-01-2011-B002

Kitchen, P. J., Kerr, G., Schultz, D. E., McColl, R., \& Pals, H. (2014). The elaboration likelihood model: Review, critique \& research agenda. European Journal of Marketing, 48(11/12), 2033-2050. https://doi.org/10.1108/EJM-12-2011-0776

Kivinen, S. (2014). Advertising execution styles as a reflection of culture. Cross-cultural analysis of messaging app advertising preferences in South Korea and China (Unpublished Master's Thesis). University Umea, Sweden. Retrieved from http://www.diva-portal.org/smash/get/diva2:747679/FULLTEXT01.pdf

Kline, R. B. (2016). Principles \& practice of structural equation modeling (4th ed.). London: The Guilford Press.

Koch, S., \& Tritscher, F. (2017). Social media in the airline industry: Acceptance of social seating. Journal of Hospitality and Tourism Technology, 8(2), 256-279. https://doi.org/10.1108/JHTT-11-2016-0078

Kotler, P. (1972). A generic concept of marketing. Journal of Marketing, 36(2), 46-54. https://doi.org/10.1177/002224297203600209

Kotler, P., Hermawan, K., \& Setiawan, I. (2010). Marketing 3.0: From products to customers to the human spirit. New Jersey: John Wiley \& Son Inc.

Kumar, V., \& Kaushik, A. K. (2018). Building consumer-brand relationships through brand experience and brand identification. Journal of Strategic Marketing, 1-21. https://doi.org/10.1080/0965254x.2018.1482945

Kwok, L., \& Yu, B. (2013). Spreading social media messages on Facebook: An analysis of restaurant business-to-consumer communications. Cornell Hospitality Quarterly, 54(1), 84-94.

https://doi.org/10.1177/1938965512458360 
Laskey, H. A., Day, E., \& Crask, M. (1989). Typology of main message strategies for television commercials. Journal of Advertising, 18(1), 36-41. Retrieved from https://www.jstor.org/stable/4188709

Lee, D., Hosanagar, K., \& Nair, H. (2018). Advertising content \& consumer engagement on social media: Evidence from Facebook. Management Science. https://dx.doi.org/10.2130/ssrn.2290802

Lee, J., \& Hong, I. B. (2016). Predicting positive user responses to social media advertising: The roles of emotional appeal, informativeness and creativity. International Journal of Information Management, 36(3), 360-373. https://doi.org/10.1016/j.ijinfomgt.2016.01.001

Lehnert, K., Till, B. D., \& Carlson, B. D. (2013). Advertising creativity and repetition. International Journal of Advertising: The Review of Marketing Communications, 32(2), 211-231. https://doi.org/10.2501/IJA-32-2-211-231

Leung, X. Y., Bai, B., \& Sathura, K. A. (2013). The marketing effectiveness of social media in the hotel industy: A comparison of Facebook \& Twitter. Journal of Hospitality \& Tourism Research, 39(2), 147-169. https://doi.org/10.1177/1096348012471381

Levin, E., Quach, T. N., \& Thaichon, P. (2019). Enhancing client-agency relationship quality in the advertising industry. Journal of Business \& Industrial Marketing, 34(2), 463-473. https://doi.org/10.1108/JBIM-08-2017-0186

Lewis-Beck, M., Bryamn, A., \& Liao, T. F. (2004). R-squared. Sage Encyclopedia of Social Science Research Methods. https://dx.doi.org/10.4135/9781412950589

Lindgreen, A., \& Vanhamme, J. (2005). Viral marketing the use of surprise. In I. Clarke \& T. B. Flaherty Advances in electronic marketing. Idea Group Publishing.

Loeffler, T. (2004). A photo elicitation study of the meanings of outdoor adventure experiences. Journal of Leisure Research, 36(4), 536-557. https://doi.org/10.1080/00222216.2004.11950035

Luarn, P., Lin, Y. F., \& Chiu Y. P. (2015). Influence of Facebook brand-page posts on online engagement. Online Information Review, 39(4), 1-28. https://doi.org/10.1108/OIR-01-2015-0029

Macedo, L., \& Cardoso, A. (2000). Towards artificial forms of surprise and curiosity. Proceedings of the European Conference on Cognitive Science, 139-144.

Malhotra, M. K., Kim, S. S., \& Patil, A. (2006). Common method variance in IS research: A comparison of alternative approaches \& a reanalysis of past research. Management Science, 52, 1865-1883. https://doi.org/10.1287/mnsc.1060.0597

Malhotra, N. K. (2010). Marketing Research: An Applied Orientation (6th ed.). New South Wales, NSW: Prentice Hall.

Malthouse, E. C., \& Calder, B. J. (2011). Comment: engagement \& experiences: comment on Brodie, Hollebeek, Juric \& Ilic 2011. Journal of Service Research, 14(3), 277-279. https://doi.org/10.1177/1094670511414584

Marketing Science Institute [MSI]. (2014). Marketing Science Institute Research Priorities 2014-2016. US: Marketing Science Institute.

Marketing Science Institute [MSI]. (2016). Marketing Science Institute Research Priorities 2014-2016. US: Marketing Science Institute.

Marketing Science Institute [MSI]. (2018). Marketing Science Institute Research Priorities 2018-2020. US: Marketing Science Institute.

McDonald, M. G. (2007). The nature of epiphanic experience. Journal of Humanistic Psychology, 48(1), 89-115. https://doi.org/10.1177/0022167807311878

McGovern, C. (2006). Sold American: consumption and citizenship, 1890-1945. Chapel Hill: University of North Carolina Press. https://doi.org/10.5149/9780807876640_mcgovern

Mehmetoglu, M., \& Engen, M. (2011). Pine and Gilmore's concept of experience economy and its dimensions: an empirical examination in tourism. Journal of Quality Assurance in Hospitality \& Tourism, 12(4), 237-255. https://doi.org/10.1080/1528008X.2011.541847

Mellers, B., Fincher, K., Drummond, C., \& Bigony, M. (2012). Surprise: a belief or an emotion? Progress in Brain Research. Amsterdam: Elsevier.

Michelli, J. (2007). The Starbucks experience: 5 principles for turning ordinary into extraordinary. New York: 
McGraw Hill.

Mollen, A., \& Wilson, H. (2010). Engagement, telepresence and interactivity in online consumer experience: Reconciling scholastic and managerial perspectives. Journal of Business Research, 63(9-10), 919-925. https://doi.org/10.1016/j.jbusres.2009.05.014

Moore, M. G., \& Diehl, W. (2019). Handbook of distance education. New York, Routledge: Taylor\& Francis.

Moors, A. (2009). Theories of emotion causation: A review. Cognition \& Emotion, 23(4), $625-662$. https://doi.org/10.1080/02699930802645739

Moors, A., Ellsworth, P. C., Scherer, K., \& Frijda, N. (2013). Appraisal theories of emotion. State of the art and future development. Emotion Review, 5(2), 119-124. https://doi.org/10.1177/1754073912468165

Morgan-Thomas, A., \& Veloutsou, C. (2013). Beyond technology acceptance: brand relationships and online brand experience. Journal of Business Research, 66(1), 21-27. https://doi.org/10.1016/j.jbusres.2011.07.019

Morris, M. H., Pryor, C. G., Schindehutte, M., \& Kuratko, D. F. (2012). Entrepreneurship as experience: how events create ventures and ventures \& venture create entrepreneurs. USA: Edward Elgar Publishing Inc.

Nichols, W. (2013). Harvard Business Review: Advertising Analytics 2.0. Retrieved from https://hbr.org/2013/03/advertising-analytics-20

Nielsen, E. M. (2015). Understanding generation $Y$ and their buying power. Retrieved from https://www.linkedin.com/pulse/understanding-generation-y-buying-power-egil-moller-nielsen

NIIT Technologies. (2013). Social media for airline industry. Retrieved from https://fdocuments.net/document/social-media-in-airline-industry-niit-techcom-media-in-as-quality-service. html

Nystrom, H. (2000). The postmodern challenge: From economic to creative management. Creativity and Innovation Management, 9(2), 109-114. https://doi.org/10.1111/1467-8691.00163

O’brien, R. M. (2007). A caution regarding rules of thumb for variance inflation factors. Quality \& Quantity, 41(5), 673-690. https://doi.org/10.1007/s11135-006-9018-6

Oh, J., Bellur, S., \& Sundar, S. S. (2015). Clicking, assessing, immersing, and sharing: An empirical model of user engagement with interactive media. Communication Research, 45(5), 737-763. https://doi.org/10.1177/0093650215600493

Ortony, A., Clore, G., \& Collins, A. (1994). The cognitive structure of emotion. United Kingdom: Press Syndicate of the University of Cambridge.

Ostroff, W. L. (2016). Cultivating Curiosity in K-12 Classrooms: How to Promote \& Sustain Deep Learning. USA: USA Association for Supervision and Curriculum Development.

Palazon, M., Scillia, M., \& Lopez, M. (2015). The influence of Facebook friends on the intention to join brand pages. Journal of Product \& Brand Management, 24, 580-595. https://doi.org/10.1108/JPBM-08-2014-0696

Palmatier, R. W., Kumar, V., \& Harmeling, C. M. (2017). Customer engagement marketing. UK: Palgrave Macmillan.

Palmer, A. (2010). Customer experience management: A critical review of an emerging idea. Journal of Services Marketing, 24(3), 196-208. https://doi.org/10.1108/08876041011040604

Pancer, E., Chandler, V., Poole, M., \& Noseworthy, T. (2018). How readability shapes social media engagement. Journal of Consumer Psychology, 1-9. https://doi.org/10.1002/jcpy.1073

Parsons, H. P. (1969). A philosophy of wonder in philosophy \& phenomenological research. International Phemenological Society, 30(1), 84-101. Retrieved from http://www.jstor.org/stable/2105923

Pham, M. T. (2013). The seven sins of consumer psychology. Journal of Consumer Psychology, 23(4), 411-423. https://doi.org/10.1016/j.jcps.2013.07.004

Pina-Garcia, C. A., \& Gu, D. (2013). Collecting random samples from Facebook: an efficient heuristic for sampling large and undirected graphs via a Metropolis-Hastings random walk. IEEE International Conference on Systems, Man, and Cybernetics.

Pina-García, C. A., Gershenson, C., \& Siqueiros-García, J. M. (2016). Towards a standard sampling methodology on online social networks: collecting global trends on Twitter. Applied Network Science, 1(1). 
https://doi.org/10.1007/s41109-016-0004-1

Pine, J. B., \& Gilmore, J. H. (1999). The experience economy: work is theatre \& every business a stage. Harvard Business School Press.

Plessis, C. (2015). Brand story telling: the case of Coca-Cola's journey corporate website. Communitas, 84-103. Pretoria: University of South Africa.

Podsakoff, P. M., MacKenzie, S. B., \& Podsakoff, N. P. (2003). Common method biases in behavioral research: a critical review of the literature and recommended remedies. Annual Review of Psychology, 63(1), 539-569. https://doi.org/10.1037/0021-9010.88.5.879

Pouraza, N., Pare, V., \& Saniee, A. (2015). Brand passion: what would customers do for their favourite brands. Melbourne International Business \& Social Sciences Research Conference, 1-11. Australia.

Rahim, K., \& Clemens, B. (2012). Organizational goals and performance measurement criteria for content marketing. Journal of Communication \& Computer, 9(8), 896-904. Retrieved from

http://docplayer.net/11225254-Organizational-goals-and-performance-measurement-criteria-for-content-mar keting.html

Rahim, N. Z., Abidin, Z. S., \& Abidin, W. Z. (2015). The Habits of Social Networking Use among Postgraduate Students. Journal Technology, University Technology Malaysia, 76(1). https://doi.org/10.11113/jt.v76.3820

Ranasinghe, V. R., \& Samarasinghe, S. M. (2019).The effect of workplace spirituality on innovative work behavior. International Business Research, 12(12), 29-38. https://doi.org/10.5539/ibr.v12n12p29

Rancati, E., \& Gordini, N. (2014). Content marketing metrics: Theoretical aspects and empirical evidence. European Scientific Journal, 10(34), 92-104.

Regan, P. (2011). Close Relationship. New York, NY: Routledge.

Reio, T. G., \& Shuck, B. (2014). Exploratory factor analysis. Advances in Developing Human Resources, 17(1), 12-25. https://doi.org/10.1177/1523422314559804

Reio, T., \& Choi, N. (2004). Novelty seeking in adulthood: Increases accompany decline. The Journal of Genetic Psychology. Research and Theory on Human Development, 165(2), 119-13. https://doi.org/10.3200/GNTP.165.2.119-133

Reisensein, R. (2000). The subjective experience of surprise. The message within the role of subjective experience in social cognition and behaviour. Washington: Philadelphia Psychology Press, 262-279.

Reisenzein, R., Meyar, W. U., \& Schutzwohl, A. (1996). Reactions to surprising events: a paradigm for emotion research. Proceedings of the 9th Conference of the International Society for Research on Emotions, 292-296.

Reitz, A. R. (2012). Online Consumer Engagement: Understanding the Antecedents and Outcomes (Unpublished doctoral dissertation). Colorado State University, Fort Collins, Colorado.

Reynaldo, J., \& Santos, A. (1999). Cronbach's Alpha: a tool for assessing the reliability of scales. The Journal of Extension, 37(2). Retrieved from https://www.joe.org/joe/1999april/tt3.php/journal-current-issue.php

Rich, B. L., Lepine, J. A., \& Crawford, E. R. (2010). Job engagement: antecedents and effects on job performance. Academy of Management Journal, 53(3), 617-635. https://doi.org/10.5465/AMJ.2010.51468988

Rider, R. (2009). Colour psychology \& graphic design application colour psychology (Unpublished Thesis). Liberty University, US. Retrieved from https://digitalcommons.liberty.edu/cgi/viewcontent.cgi?article=1118\&context=honors

Riva, G., Wiederhold, B. K., \& Pietro, C. (2016) .The psychology of social networking vol.1. personal experience in online communities. Berlin: De Gruyter. https://doi.org/10.1515/9783110473780

Roni, M. S. (2015). An analysis of insider dysfunctional behaviours in an accounting information system environment (Unpublished Doctoral Thesis). Edith Cowan University, Australia. Retrieved from http://ro.ecu.edu.au/theses/1640

Rothenberg, A. (1986). Artistic creation as stimulated by superimposed versus combined-composite visual images. Journal of Personality and Social Psychology, 50(2), 370-381.

https://doi.org/10.1037//0022-3514.39.5.953 
Ryan, R. M., \& Deci, E. L. (2000a). Intrinsic \& extrinsic motivations: Classic definitions \& new directions. Contemporary Education Psychology, 25, 54-67. https://doi.org/10.1006/ceps.1999.1020

Ryan, R. M., \& Deci, E. L. (2000b). Self-Determination Theory \& the Facilitation of intrinsic motivation, social development and well-being. American Psychologist Association, 55(1), 68-78. https://doi.org/10.1037/0003-066X.55.1.68

Sabate, F., Berbegal-Mirabent, J., Canabate, A., \& Lebherz, P. (2014). Factors influencing popularity of branded content in Facebook fan pages. European Management Journal, 32, 1001-1011.

Sabharwal, D. (2018). Fundamentals of advertising \& public relation. India: Evinvepub Publishing.

Saunders, M., Lewis, P., \& Thornhill, A. (2009). Research methods for business student. US: Prentice Hall.

Schaufeli, W. B. (2013). What is engagement? Employee engagement in theory \& practice. London: Routledge.

Schmitt, B. (1997). Superficial out of profundity: the branding of customer experiences. The Journal of Brand Management, 5(2), 92-98. https://doi.org/ 10.1057/bm.1997.35

Schmitt, B. (2009). The concept of brand experience. Journal of Brand Management, 16, 417-419. https://doi.org/10.1057/bm.2009.5

Schmitt, B. (2011). Experience marketing: concepts, frameworks and consumer insights. Foundations \& Trends in Marketing, 5(2), 55-112. http://dx.doi.org/10.1561/1700000027

Schmitt, B. (1999). Experiential marketing. Journal of Marketing Management, 15(1-3), 53-67. https://doi.org/10.1362/026725799784870496

Schmitt, B., \& Zarantonello, L. (2013). Consumer experience \& experiential marketing: A critical review. Review of Marketing Research, 10, 25-61. https//doi.org/10.1108/S1548-6435(2013)0000010006

Schouten, J. W., McAlexander, J. H., \& Koenig, H. F. (2007). Transcedent customer experience and brand community. Journal of the Academy of Marketing Science, 35, 357-368. https://doi.org/10.1007/s11747-007-0034-4

Sharifian, F. (2014). Advances in Cultural Lingusitics. Spain: Springer.

Shaw, E. H., \& Jones, D. G. B. (2005). A history of schools of marketing thought. Marketing Theory, 5(3), 239-281. https://doi.org/10.1177/1470593105054898

Sheth, J. N., \& Parvatiyar, A. (1995a). The evolution of relationship marketing. International Business Review, 4(4), 397-418. https://doi.org/10.1016/0969-5931(95)00018-6

Sheth, N. J., \& Parvatiyar, A. (1995b). Relationship marketing in consumer markets: Antecedents \& consequences. Journal of the Academy of Marketing Science, 23(4), 225-271.

Shouse, E. (2005). Feeling, emotion, affect. Journal Media Culture, 8(6).

Shrotryia, V. K., \& Dhanda, U. (2019). Content validity of assessment instrument for employee engagement. Sage Open, 1-7. https://doi.org/10.1177/2158244018821751

Silvia, P. J. (2005). What is interesting? Exploring the appraisal structure of interest. Emotion, 5, 89-102.

Simon, C., Brexendorf, T., O., \& Fassnacht, M. (2013). Creating online brand experience on Facebook. Marketing Review St. Gallen, 30(6), 50-59. https://doi.org/10.1365/s11621-013-0299-6

Simonton, K. D. (2012). Taking the U.S. patent office criteria seriously: A quantitative three-criterion creativity definition and its implications. Creativity Research Journal, 24(2-3), 97-106. https://doi.org/10.1080/10400419.2012.676974

Sivertzen, A. M., Nisen, E., \& Olafsen, A. H. (2013). Employer branding: employer attractiveness and the use of social media. Journal of Product \& Brand Management, 22(7), 473-483. https://doi.org/10.1108/JPBM-09-2013-0393

Skard, S., Nysveen, H., \& Pedersen, P. E. (2011). Brand and customer experience in service organizations: literature review and brand experience construct validation. Bergen: Working Paper.

Smilansky, S. (2009). Experiential marketing: A practical guide to interactive brand experiences. London: Kogan.

Smith, S. (2013). Conceptualising \& evaluating experiences with brands on Facebook. International Journal of Market Research, 55(3), 357-374 https://doi.org/10.2501/IJMR-2013-034 
Snel, J. M. C. (2011). For the love of experience: changing the experience economy discourse (Unpublished Phd Thesis). University of Amsterdam, Netherlands. Retrieved from https://dare.uva.nl/search?identifier=cea6329e-e58f-4dff-8ab9-4a5e6b2b1c9f

So, J., Achar, C., Han, D., Agrawal, N., Duhacej, A., \& Maheswaran, D. (2015). The psychology of appraisal: Specific emotion and decision-making. Journal of Consumer Psychology, 25(3), 359-371. https://doi.org/10.1016/j.jcps.2015.04.003

Social Bakers Report. (2014). Top social care industry. Retrieved from https://cdn.socialbakers.com/www/static/build.1799767479/www/media/data/sociallydevoted-q4-2014.png

Solem, B. A. A. (2015). The Process of Customer Brand Engagement in Interactive Contexts: Prerequisites, Conceptual Foundations, Antecedents, and Outcomes. (Unpublished doctoral dissertation). Thesis of Department of Strategy and Management, University College of Southeast Norway, School of Economics and Business Administration, Norwegian. Retrieved from https://openaccess.nhh.no/nhh-xmlui/bitstream/handle/11250/2412903/Solem_PhD_thesis.pdf?sequence=1

Solem, B. A. A. (2016). Influences of customer participation and customer brand engagement on brand loyalty. Journal of Consumer Marketing, 33(5), 332-342. https://doi.org/10.1108/JCM-04-2015-1390

Statista. (2018). Facebook activities of users in the United States 2017. Retrieved from https://www.statista.com/statistics/275788/share-of-facebook-user-activities/

Statista. (2019a). Malaysia: Total population from 2014 to 2024 (in million inhabitants). Retrieved from https://www.statista.com/statistics/318725/total-populationof-malaysia/

Statista. (2019b). Number of social network users in Malaysia from 2017 to 2023 (in millions). Retrieved from https://www.statista.com/statistics/489233/number-of-socialnetwork-

Stelzner, M. (2018). Social media marketing industry report 2018.US: Social Media Examiner.

Stevenson, A. (2010). Oxford dictionary of English. Oxford University Press, England.

Swani, K., Milne, G. R., \& Brown, B. P. (2013). Spreading the word through likes on Facebook: evaluating the message strategy effectiveness of fortune 500 companies. Journal of Research in Interactive Marketing, 7(4), 269-294. https://doi.org/10.1108/JRIM-05-2013-0026

Sweetman, B. (2005). Lyotard, postmodernism and religion. Philosophia Christi, 7(1), 139-151. https://doi.org/10.5840/pc20057114

Syrdal, H. A., \& Briggs, E. (2018). Engagement with social media content: A qualitative exploration. Journal of Marketing Theory and Practice, 26(1-2), 4-22. https://doi.org/ 10.1080/10696679.2017.1389243

Tafesse, W. (2015). Content strategies and audience response on Facebook brand pages. Marketing Intelligence \& Planning, 33(6), 927-943. https://doi.org/10.1108/MIP-07-2014-0135

Tafesse, W. (2016). An experiential model of consumer engagement in social media. Journal of Product \& Brand Management, 25, 424-434. https://doi.org/10.1108/JPBM-05-2015-0879

Tafesse, W., \& Wein, A. (2017). A framework for categorizing social media posts. Journal Cogent Business \& Management, 4, 1-22. https://doi.org/10.1080/23311975.2017.1284390

Tafesse, W., \& Wien, A. (2018). Using message strategy to drive consumer behavioral engagement on social media. Journal of Consumer Marketing, 35(3), 241-253. https://doi.org/10.1108/JCM-08-2016-1905

Takalani, M. (2015). A review and analysis of the role of integrated marketing communication message typology in the development of communication strategies. African Journal of Marketing, 7(8), 90-97. https://doi.org/10.5897/AJMM2015.0475

Taylor, D. G., Lewin, J. E., \& Strutton, D. (2011). Friends, fans \& followers: do ads work on social networks, 5(1), 258-275. Journal of Advertising Research, 258-277. https://doi.org/10.2501/JAR-51-1-258-275

Terkan, R. (2014). Importance of creative advertising and marketing according to university students' perspective. International Review of Management and Marketing, 4(3), 239-234. Retrieved from https://docplayer.net/32365727-Importance-of-creative-advertising-and-marketing-according-to-university-s tudents-perspective.html

The Star. (2018, November 3). Star Special: The most prestigious brand awards 2018. Malaysia: The Star Newspaper, p. 1-48. 
Ting, H., Lim, T. Y., de Run, E. C., Koh, H., \& Sahdan, M. (2018). Are we baby boomers, gen X and gen Y? A qualitative inquiry into generation cohorts in Malaysia. Kasetsart Journal of Social Sciences, 39(1), 109-115. https://doi.org/10.1016/j.kjss.2017.06.004

Toyama, M., \& Yamada, Y. (2012). The relationships among tourist novelty, familiarity, satisfaction, and destination loyalty: beyond the novelty-familiarity continuum. International Journal of Marketing Studies, 4(6). https://doi.org/10-18. 10.5539/ijms.v4n6p10

Trefzger, T. F., Baccarella, C. V., \& Voigt, K. I. (2016). Antecedents of brand post popularity in Facebook:the influence of images, videos, and text. International Marketing Trends Conference, 1-8.Venice.

Trigg, S. (2014). Introduction: emotional histories: beyond the personalization of the past and the abstraction of affect theory. Exemplaria, 26(1), 3-15. https://doi.org/10.1179/1041257313Z.00000000043

Trusov, M., Bodapati, V. A., \& Bucklin, R. E. (2010).Determining influential users in internet social networks. Journal of Marketing Research, 47(4), 643-658. https://doi.org/10.1509/jmkr.47.4.643users-in-Malaysia/

Valentina, P., \& Laurence, D. (2019). How stories generate consumer engagement: An exploratory study. Journal of Business Research, 104, 183-195. https://doi.org/10.1016/j.jbusres.2019.06.045

Vallerand, J. R. (1997). Toward a hierarchical model of intrinsic \& extrinsic motivation. Advances in Experimental Social Psychology, 29, 1-90. https://doi.org/10.1016/S0065-2601(08)60019-2

Van Doorm, J., Katherine E. L., Vikas M., Stephan N., Pick D., Peter P., \& Peter C. V. (2010). Customer engagement behaviour: Theoretical foundations and research directions. Journal of Service Research, 13(3), 253-266. https://doi.org/10.1177/1094670510375599

Vaughan, K., Beal, V., \& Romaniuk, J. (2016). Can brand users really remember advertising more than non-users. Journal of Advertising Research, 56(3), 311-321. https://doi.org/10.2501/JAR-2016-037

Verhoef, P. C., Reinartz, W. J., \& Krafft, M. (2010). Customer engagement as a new perspective in customer management. Journal of Service Research, 13, 247-252. https://doi.org/10.1177/1094670510375461

Viechtbauer, W., Smits, L. Kotz, D., Bude, L., Spigt, M., Serroyen, J., \& Crutzen, R. (2015). A simple formula for the calculation of sample size in pilot studies. Journal of Clinical Epidemiolology, 68(11), 1357-1359. https://doi.org/10.1016/j.jclinepi.2015.04.014

Vollero, A., \& Palazzo, M. (2015). Conceptualizing content marketing: A delphi approach. Mercati \& Competitività, 1, 25-44. http://doi.org/10.3280/MC2015-001003

Walls, A. R., Okumus, F., Wang, Y., \& Kwun, J., D. (2011). An epistemological view of consumer experiences. International Journal of Hospitality Management, 30(1), 10-21. https://doi.org/10.1016/j.ijhm.2010.03.008

Wang, W. L., Malthouse, E. C., Calder, B., \& Uzunoglu, E. (2019). B2B content marketing for professional services: in person versus digital contacts. Industrial Marketing Management, 81, 160-168. https://doi.org/10.1016/j.indmarman.2017.11.006

Watsons, J. C. (2017). Establishing evidence for internal structure using exploratory factor analysis. Measurement \& Evaluation in Counseling \& Development, 50(4), 232-238. https://doi.org/10.1080/07481756.2017.1336931

Weilbacher, W. M. (2001). Point of view: does advertising cause a "hierarchy of effects"? Journal of Advertising Research, 41(6), 19-26. https://doi.org/10.2501/JAR-41-6-19-26.

Weisberg, R. W. (2015). On the usefulness of "value" in the definition of creativity. Creativity Research Journal, 27(2), 111-124. https://doi.org/10.1080/10400419.2018.1411432

Whiting, D. (2009). The feeling theory of emotion and the object directed emotions. European Journal of Philosphy, 19(2), 281-303. https://doi.org/10.1111/j.1468-0378.2009.00384.x

Wided, B. (2012). An overview of postmodern research in the consumer behaviour field: towards the "new consumer" paradigm. Advances in Consumer Research, 9, 304-312. Retrieved from http://www.acrwebsite.org/volumes/1008893/volumes/ap09/AP-09

Yilmaz, R. (2017). Narrative advertising models and conceptualization in the digital age. Hershey: IGI Global Publishing Academic Research.

Zamanzadeh, V., Ghahramanian, A., Rassouli, M., Abbaszadeh, A., Alavi-Majd, H., \& Nikanfar, A. (2015). Design and implementation content validity study: development of an instrument for measuring patient-centered communication. Journal of Caring Science, 4(2), 1651-1678. 
https://doi.org/10.15171/jcs.2015.017

Zatori, A. (2013). Tourism experience creation from a business perspective (Unpublished Phd Thesis). Corvinus University of Budapest, Hungary. Retrieved from http://phd.lib.uni-corvinus.hu/801/7/Zatori_Anita_den.pdf

Zhanetta, G. (2011). Eureka! Unravelling the mystery behind creativity. New York: Columbia University.

Zhou, J., Wang, X. M., Song, L. J., \& Wu, J. (2017). Is it new? Personal and contextual influences on perceptions of novelty and creativity is it new? Journal of Applied Psychology, 102(2), 180-202. https://doi.org/10.1037/apl0000166

\section{Appendix}

\section{MORE FACE-TO-FACE BUSINESS. NOW ACCESSIBLE FIVE TIMES A DAY.}

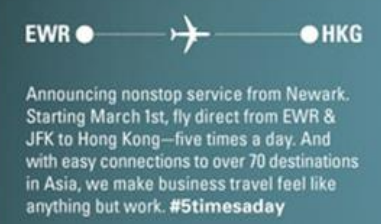

anything but work. \#5timesaday

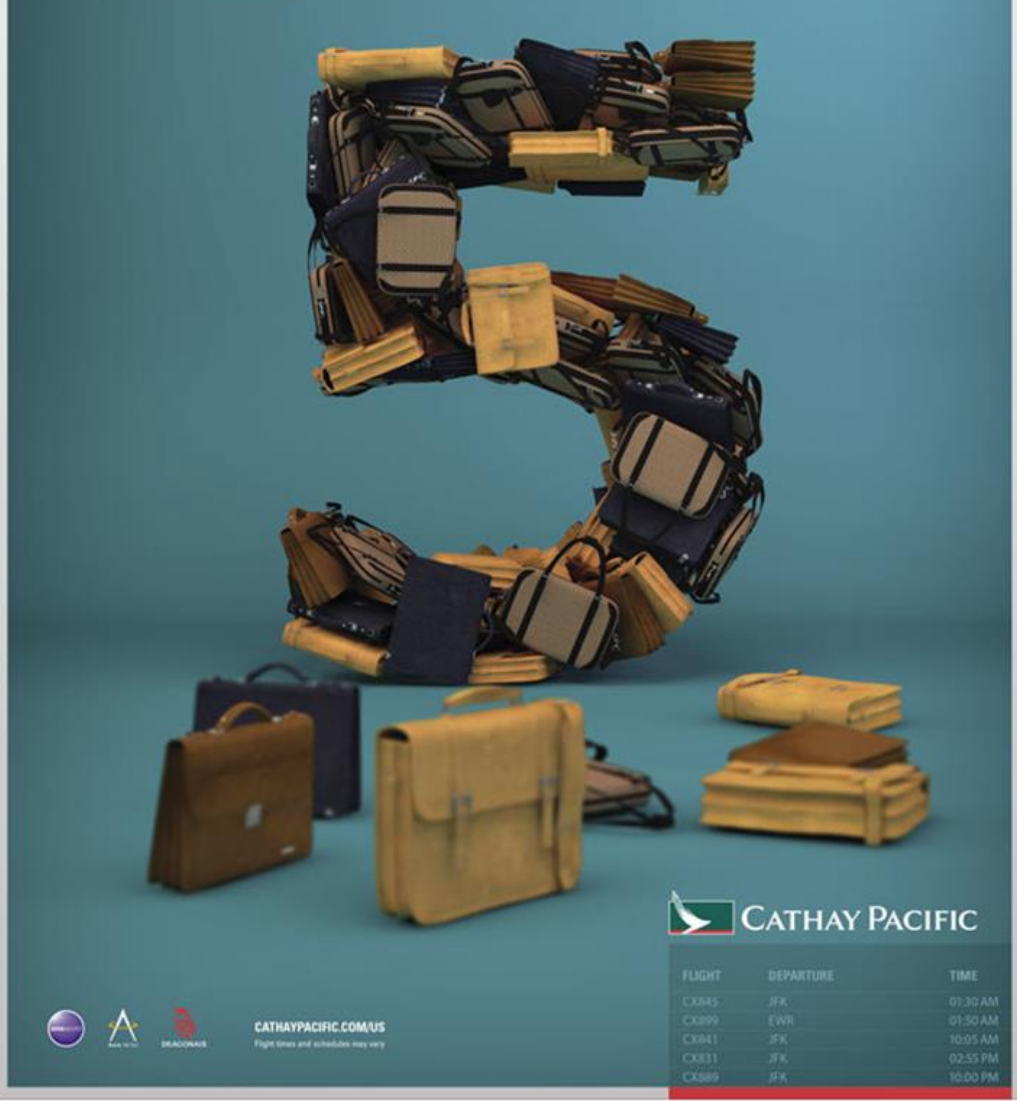

\section{Copyrights}

Copyright for this article is retained by the author(s), with first publication rights granted to the journal.

This is an open-access article distributed under the terms and conditions of the Creative Commons Attribution license (http://creativecommons.org/licenses/by/4.0/). 